\title{
A CHARTALIST VIEW OF NUMISMATICS \\ (FUNDAMENTS AND NECESSITIES OF THE DISCIPLINE 30 YEARS AFTER THE WORK BY PETER SPUFFORD: MONEY AND ITS USE IN MEDIEVAL EUROPE)
}

\author{
Xavier Sanahuja-Anguera \\ Societat Catalana d'Estudis Numismàtics \\ SPAIN
}

Date of receipt: $13^{\text {th }}$ of July, 2016

Final date of acceptance: $7^{\text {th }}$ of November, 2016

\section{Abstract}

From a chartalist, non-monetarist starting point, the author analyses basic concepts of numismatics and the history of money, auxiliary disciplines of History, focussing on the medieval epoch and indicating its shortcoming in Catalonia and Spain. ${ }^{1}$

\section{KEYWORDS}

Chartalism, Coin, Currency, Monetarism, Money, Numismatics.

\section{Capitalia Verba}

Chartalismus, Moneta, Nummus, Monetarismus, Pecunia, Nummismatica. 


\section{Definitions and prior considerations in numismatics and currency}

\subsection{Numismatics, a scientific discipline}

Numismatics is the auxiliary discipline of history responsible for the study of currency systems, coins and other examples of official tender over history. Secondly, numismatics also studies those objects that have morphological (medals, getons) or functional (tokens, vouchers) similitudes with money.

Because of its character as an auxiliary discipline, numismatics needs to be approached with a scientific method. Coins are historical documents that must be studied and defined with scientific criteria before being used for historical interpretation. With this, I refer to a certain currency produced in a specific year, that circulated until another year, which was worth a certain amount, that people paid for with a mark-up that was so and so, etc. These are indisputable data. They can be right or wrong, but not debatable. The historian, through numismatics and the scientific method, needs to be able to refute mistaken perceptions and carry out a correct heuristic task. Historians necessarily require that the auxiliary disciplines of history that supply them with information have been established and filled through the strictest of scientific methods.

Throughout the $20^{\text {th }}$ century, the great reference work for European medieval money has traditionally been the extensive manual by Engel and Serrure, published in three volumes between 1891 and $1905 .^{2}$ This was a geographic and chronological collection of European medieval monetary issues. The information for this work came from national numismatic catalogues from the second half of the $19^{\text {th }}$ century: Poey d'Avant (1862), Heiss (1869), etc. ${ }^{3}$ For example, following the criterion of Poey d'Avant, Engel and Serrure placed Catalan numismatics in French settings until the times of James I. ${ }^{4}$ Although the book was published around 1900, it is still an omnipresent reference in any article or study at university level published nowadays. This is surprising because, at least in the case of the three regions I know best (Catalonia-Aragon, Castile-Leon, and Occitania),

\footnotetext{
1. Translations of non-English literal quotations have been made by the editorial team of the journal.

2. Engel, Arthur; Serrure, Raymond. Traité de numismatique du Moyen Age. Paris: Ernest Leroux, 1891-1905 (3 volumes) (reprinted: Bologna: Arnaldo Forni, 1964). However, in France, it has shared with, and ceded prominence to, the work by Adrien Blanchet and Adolphe Dieudonné: Blanchet, Adrien; Dieudonné, Adolphe. Manuel de numismatique française. Vol. 1. Monnaies frappés en Gaule depuis les origines jusqu'a Hughes Capet. Paris: A. Picard, 1912; Blanchet, Adrien; Dieudonné, Adolphe. Manuel de numismatique française. Vol. 2. Monnaies royales françaises depuis Hughes Capet jusqu'a la revolution. Paris: A. Picard, 1916; Blanchet, Adrien; Dieudonné, Adolphe. Manuel de numismatique française. Vol. 3. Medailles, jetons, mereaux. Paris: A. Picard, 1930; Blanchet, Adrien; Dieudonné, Adolphe. Manuel de numismatique française. Vol. 4. Monnaies féodales françaises. Paris: A. Picard, 1936.

3. Poey d'Avant, Fautin. Monnaies féodales françaises. Paris: 1858-1862 (4 volumes) (reprinted in 3 volumes In: Graz: Akademische Druck- u. Verlagsanstalt, 1961; and, in a paperback version, in: Paris: Maison Florange, 1995); Heiss, Aloïss. Descripción general de las monedas hispano-cristianas desde la invasión de los árabes. Madrid: R. N. Milagro, 1865-1869.
}

4. Engel, Arthur; Serrure, Raymond. Traité de numismatique...: 437-446. 
the numismatic paradigm has changed to an unimaginable degree between 1900 and the present. ${ }^{5}$ The formal presentation by Engel and Serrure was adopted and improved in all later general works. In these, even the more recent ones, the evolution of monetary emissions is always presented divided into stages, which in Engel and Serrure were not only strictly chronological, but later became dominated by a certain type of coin: the stage of the penny, ${ }^{6}$ the stage of the gros, the stage of the florin, etc. This periodisation often excludes such themes as access to precious metals, intercontinental trade relations and also to the solidity of the political states minting money. The formal synthetic continuity of the work by Engel and Serrure contrasts with the rupture that occurred, in parallel, in numismatic research. The rupture consisted of a division of the central trunk into three branches, apparently complementary but which have often been hostile to each other.

In first place, these branches are the description, correct attribution and cataloguing of the monetary examples conserved over time; secondly, the understanding of the practical working of physical money in the monetary system in each territory and at a certain time; and, in third place, the global comprehension

\begin{abstract}
5. As examples, illustrating the strictly Catalan case to avoid unnecessarily extending the story, in 1905 the work by Joaquim Botet (Botet, Joaquim. Les monedes catalanes. Barcelona: Institut d'Estudis Catalans, 1908-1911 [3 volumes], republished: Barcelona: Puvill, 1976) had not yet been published; only a few dozen types of county coins were known physically, while nowadays, over five hundred are known (Balaguer, Anna Maria. Història de la moneda dels comtats catalans. Barcelona: Societat Catalana d'Estudis Numismàtics, 1999); very little was known about local and municipal coinage (Crusafont, Miquel. La moneda catalana local, segles XIII-XVIII. Barcelona: Societat Catalana d'Estudis Numismàtics, 1990); the 15 th entury monetary problems and their repercussion on Barcelonan policy had not been studied (Batlle, Carme. La crisis social y económica de Barcelona a mediados del siglo XV. Barcelona: Consejo Superior de Investigaciones Científicas, 1973; Crusafont, Miquel. Barcelona i la moneda catalana. Barcelona: La Caixa, 1989); it was believed that the coins with the name of Ferdinand the Catholic belonged to his epoch and not that they were minted until 75 years after his death (Sanahuja, Xavier. "Rals i croats catalans del segle XVI". Acta Numismàtica, 30 (2000): 95-130); the series of gold florins of Aragon had not been dated and the mints where it was issued had not even been identified (Crusafont, Miquel; Comas, Rafael. El florí d'or català: Catalunya, València, Mallorca. Barcelona: Asociación Numismática Española-Societat Catalana d'Estudis Numismàtics, 1996); no Catalan coins attributed to the $10^{\text {th }}$ century were known (Sanahuja, Xavier. "Les monedes de Barcelona del segle X, segons les troballes Espanya-1 i Espanya-2 (925)". Acta Numismàtica, 36 (2006): 79-113); it was thought that the Barcelona mint had not begun to make gold ducats until 1492, eleven years after the real date (Sanahuja, Xavier. "Ducats i principats catalans a l'època dels Àustries (1481-1602)". Acta Numismàtica, 29 (1999): 105-133); the diposit of Òrrius with pieces from the $11^{\text {th }}$ century had yet to appear (Padilla, José Ignacio; Vives, Elisenda; Balaguer, Anna Maria; Crusafont, Miquel. Les excavacions a l'església de Sant Andreu. Òrrius. Estudi preliminar de la troballa de monedes comtals. Barcelona: Departament de Cultura de la Generalitat de Catalunya, 1983: 57-104); Bisson had not written the Conservation of Coinage (Bisson, Thomas N. Conservation of coinage. Monetary exploitation and its restraint in France (c.a.d. 1000 - c. 1225). Oxford: Oxford University Press, 1979), etc.
\end{abstract}

6. Curiously, the translations of English works into Spanish tend to translate the English word 'penny' into penique, and the translators of French works traductors translate denier as denario, without realising that the equivalent words and/or values were the diner in Catalan, or dinero in Spanish. Thus, when we read in any of these works the concept of a period or stage 'of the penny', for example, we should translate it as etapa del diner. An example is the translation of the work by Catherine Eagleton and Jonathan Williams: Eagleton, Catherine; Williams, Jonathan. Money a History. London: British Museum, 1997 (Revised in 2007: London: British Museum, 2007 [2 ${ }^{\text {nd }}$ Revised edition]). 
of the concept and utility of money within society. However, before explaining each of the branches in greater detail, the concept of money, veritable protagonist of the discipline, must be defined. And this is not as easy a task as it may seem.

\subsection{What is money? Origin and uses}

Catalan and Spanish use only one word, moneda, to designate two different concepts: currency and coinage. ${ }^{7}$ This is a slight linguistic handicap that can be solved by establishing a priori where each of the concepts starts and finishes. Currency is a measure of value that is used mentally to calculate transactions and the real value of the coins, which are what circulate as both an instrument and means of payment. The two definitions cited -measure of value and instrument means of payment-are valid in a descriptive sense, but must be developed to explain their existence and utility. ${ }^{8}$ To start with, it should be noted that it does not seem that the existence of one necessarily means the existence of the other. Rather, if the existence of the currency (as a measure of value) is proven in the majority of the historical societies, in contrast, coins or money have not always existed. ${ }^{9}$ We can agree that some goods or services can be valued (or their value measured) without them necessarily being exchanged for coins. ${ }^{10}$ That is why it is important to be able to identify and explain the origin and later use of coinage.

7. In contrast, German, English and French may use distinct words to differenciate the two concepts. In English: currency/coin or money (although currency may also mean any form of money when in actual use or circulation); in French: monnaie/pièce; in German: Währung/Münze. Currently, in Catalonia some sectors substitute these expressions for moneda comptable and peça de moneda respectively, which are terms that sound strange because they are forgotten..

8. The definition of money as a measure of value is by Miquel de Crusafont, who adapted the one by De Jaucourt, that appeared in volume $\mathrm{X}$ of the Encyclopédie by Diderot and D'Alembert: un signe que représente la valeur, la mesure de tous les valeurs d'usage, et est donné comme le prix de toutes choses ("A sign that represents the value, the measure of all usage values, and that is given as the price of all the things"). Crusafont, Miquel. Història de la moneda catalana. Barcelona: Crítica, 1996: 14.

9. Nearby medieval examples are those of Castile, Galícia or Navarre in the $10^{\text {th }}$ and $11^{\text {th }}$ centuries. Sánchez Albornoz, Claudio. "Moneda de cambio y moneda de cuenta en el reino asturleonés". Cuadernos de Historia de España, 31-32 (1960): 5-32; Sánchez Albornoz, Claudio. “Moneta e scambi nell'alto medioevo, Centro Italiano di studi sull'alto medioevo", VIII Settimane di Studio del Centro Italiano di Studi sull'Alto Medioevo (Spoleto, 21-27 aprile 1960). Spoleto: Centro Italiano di Studi sull'alto Medioevo, 1961: 171-202; Isla, Amancio "Moneda de cuenta y organización monetaria en la Galicia alto-medieval”, Miscel-lània en homenatge al pare Agustí Altisent. Tarragona: Diputació de Tarragona, 1991: 487-510; Ladero, Miguel Ángel. "Moneda y políticas monetarias en la Corona de Castilla (siglos XIII a XV)", Moneda y Monedas en la Europa medieval. XXVI Semana de Estudios Medievales de Estella (19 a 23 de julio de 1999). Pamplona: Gobierno de Navarra, 2000: 129-130; Crusafont, Miquel. "Significado y valor del "Sólido Gallicano" (S. X-XI)", Introducción a la Historia monetaria de Galicia, Francisco Cebreiro, ed. Santiago de Compostela: Labirinto de Paixóns S.L.: 105-116.

10. An example of this circumstance is the well-known use of the expression in rem valentem in $10^{\text {th }}$ and $11^{\text {th }}$-century documents to state that a certain payment was not made in money, but rather in another specially desired good. Bonnassie, Pierre. La Catalogne du milieu du Xe a la fin du XIe siècle: croissance et mutations d'une Société. Toulouse: Publications de l'Université de Toulouse-Le Mirail, 1975: $369-371$ 


\subsubsection{Nicole Oresme: money, a public good with commercial functionality}

Traditionally, the most widely spread and accepted definition of money is that it is an instrument whose origin derives from the need of the population to exchange the surplus production without resorting to the uncomfortable exchange of products. This theory that money is a common good, created to facilitate trade transactions must have come from ancient times. The thinker who managed to spread and perpetuate it was Nicole Oresme (circa 1323-1382), bishop of Lisieux and counsellor to Charles V of France. ${ }^{11}$ He was not the first, ${ }^{12}$ but is the one who has withstood the passing of time and influenced later authors. ${ }^{13}$ Oresme sustained that money was a product that originated in the market and not from the state, that it was another good and not only a means of exchange. He believed that private individuals had originally certified the purity of the precious metals used as money in their transactions. He also believed that monetary problems began when the states began to falsify the purity of these metals and thus provoked inflation, and that these problems worsened when the state nationalised money. ${ }^{14}$ Oresme accepted the monopolistic intervention of the kings in the issue of money, but reminded them that money was a good of public utility that they had appropriated, and he demanded that they reduce the profits from its production to the minimum, while he also found usury, mutation, the change and accumulation

(Catalan version: Bonnassie, Pierre. Catalunya mil anys enrere. Barcelona: Edicions 62, 1979-1981 [2 volumes]); Balaguer, Anna Maria. Història de la moneda dels comtats...: 41-53, 93-95.

11. An introduction to Oresme and the Spanish translation of his work Tractatus de origine et natura, iure et mutationibus monetarum can be found published by Josep Hernando (Hernando, Josep. "Tractatus de origine et natura, iure et mutationibus monetarum. Nicolas de Oresme (s. XIV). Introducción, transcripción y notas". Acta historica et Archaelogica Mediaevalia, 2 (1981): 9-65). Peter Spufford also speaks at length about it (Spufford, Peter. Money and its use in Medieval Europe. Cambridge (UK): Cambridge University Press, 1988: 372-409). Recently some supporters of Oresme have also published his work (Hülsmann, Jörg Guido. "Nicholas Oresme and the First Monetary Treatise". Mises Institute. 18 May 2004. 12 June 2016 <https://mises.org/library/nicholas-oresme-and-first-monetary-treatise>; Spanish translation: Valín, Jorge. “Traducción de Jörg Guido Hülsmann”. Jorge Valín Weblog. 30 May 2004. 12 June 2016 <https://jorgevalin.wordpress.com/2004/05/30/traduccion-de-jorg-guido-hulsmann/>; The De moneta of Nicholas Oresme and English Mint Documents, ed. and trans. Charles Johnson. London: Thomas Nelson and Sons Ltd., 1956). In fact, it is no surprise that a firm posture like Oresme's arose in Paris, as it must be placed in a context of continuous monetary mutations in France due to the war (Lafaurie, Jean. Les monnaies des rois de France. Vol. I. de Hugues Capet a Louis XII. Paris-Basel: Émile Bourgey-Monnais et Médailles S.A., 1951; Spufford, Peter. "Monetary practice and monetary theory in Europe (12th-15th centuries)", Moneda y Monedas en la Europa medieval. XXVI Semana de Estudios Medievales de Estella (19 a 23 de julio de 1999). Pamplona: Gobierno de Navarra, 2000: 53-86).

12. Before Oresme, thinkers like Pere Joan Oliu (Olivi) (1248-1298), Peter de la Palu (circa 1275-1342) and later Guiu Terrena (died in 1342), had looked into these approaches and indicated that king who only thinks about himself in monetary questions is a tyrant (Spufford, Peter. "Monetary practice...": 66). 13. Before the $15^{\text {th }}$ century, Oresme had a great influence in authors like Martín Azpilcueta, Giovanni Aquila, Jean Bodin, René Budel, Mirabeau or, nearer home, Jaume Callís.

14. Hernando, Josep. “Tractatus de origine...": 37. 
of coins, unacceptable. Oresme did not dispute the kings' right to mint them but awarded final ownership to the people. ${ }^{15}$

There is no known evidence for the supposed private inception of money beyond the plausibility of the process. In modern times, Oresme's commercial conception was set out in the $19^{\text {th }}$ century by Carl Menger, one of the founders of the Austrian School of Economics, ${ }^{16}$ and later, recurrently adopted throughout the $20^{\text {th }}$ century. ${ }^{17}$ It is true that it is not by chance that the origin of money has been related to trade given that, as John Hicks observes, ${ }^{18}$ the evolution of the barter market implies establishing products easy to store, of easy liquidity, coveted by everyone and that can act as measurers of the value of the goods of exchange at a given moment. Some products that meet these requisites are, obviously, the precious metals. Oresme, Menger and Hicks, and everyone who has taken up this mercantile evolution, has presupposed that the precious metals had to be converted, unfailingly, into measures of value accepted by everyone. However, they do not fully explain this process of conversion. The outcome could be very comfortable and practical but how does one reach the general acceptance of a measure of value? Thus, according to these authors, it came about naturally, without the intervention of the powers. ${ }^{19}$ The last sentence of Menger's article is very explicit in this sense: "All these (institutional) measures nevertheless have not first made money of the precious metals, but have only perfected them in their function as money". ${ }^{20}$ According to him, political laws did not create money but rather they perfected the use of precious metals as money. This is where the misunderstanding lay. In the $19^{\text {th }}$ century and a good part of the $20^{\text {th }}$, when talking about money, it was with the precious metals, gold and silver, in mind. It was exclusively these two that were envisaged, as they were the dominant metals in the history of western money. However, money is something more than a precious metal, ${ }^{21}$ and something more than a western invention. In fact, in the $7^{\text {th }}$ century

15. Hernando, Josep. “Tractatus de origine...": 49-50.

16. Menger, Carl. "On the origins of Money". Economic Journal, 2 (1892): 239-255.

17. Hicks, John. A Theory of Economic History. Oxford: Oxford University Press, 1960 (Spanish translation: Hicks, John. Una teoría de la historia econòmica. Barcelona: Aguilar S. A., 1974); Spufford, Peter. Money and its use....

18. Hicks, John. A Theory of Economic...: 58.

19. For example, Carl Menger states textually that: "Money has not been generated by law. In its origin it is a social, and not a state institution. Sanction by the authority of the state is a notion alien to it". And the same theorist concludes the process this way: "It was the just apprehending of their individual self-interest which brought it to pass, that all the more economically advanced nations accepted the precious metals as money as soon as a sufficient supply of them had been collected and introduced into commerce". Menger, Carl. "On the origins of Money...": 255. In other words, according to the author, it was the needs of the nations (or shall we say communities) that led naturally to the conversion of the precious metals into currency as soon as they were able to gather together enough of them.

20. Menger, Carl. "On the origins of Money...": 255.

21. Insisting more on this theme, the terms 'primitive money' or 'premoney' are used to designate not only the precious metals, but also necklaces, manufactured base metals, shells and cowries, and other objects used in the past as coveted, easily-exchangeable goods (Einzig, Paul. A Primitive Money In its Ethnological, Historical and Economic Aspects. London: Eyre \& Spottiswoode, 1949 [republished: London: 
$\mathrm{BC}$, at the same time as coinage based on gold and silver was being created in Aegina and Lydia, in China it was created based on bronze. ${ }^{22}$ It is clear that bronze has never been a precious metal, not even in China. Despite this drawback, the theory about the commercial and private origins of money was, and continues to be, accepted by many thinkers, resisting the passing of the centuries. Oresme's thought has given good foundations for the economic theory of Hayek and the Austrian School of Economics (or Vienna School), to a good extent the home of modern liberal thinking. ${ }^{23}$ The rooting of the theory of the commercial origin among thinkers and economists over the centuries has encouraged it to take root among historians, journalists and, obviously, media commentators. It thus continues to be the most widely accepted theory about the origin of currency and coins. Thus, it is rare to find research or divulgative studies, which, when talking about money, do not to link it necessarily with 'trade'. Henri Pirenne himself, for example, regarding the unique issue of silver coins in the Carolingian epoch, believed that le nouveau système, mono-métalliste argent, correspond à la regression économique à laquelle on est arrivé. ${ }^{24}$ One of those most responsible for the continuity of this discourse is Peter Spufford and the indisputable success of his work Money and its use in Medieval Europe. ${ }^{25}$ It is true that it seems that the tendency is gradually changing, but, for now, the commercial paradigm remains very solid. In fact, in any study featuring coins or money, it is usual to try to relate these concepts to trade or related economic activities, although the context seems to deny it. ${ }^{26}$ Thus,

Pergamon, 1966]). Should these be considered true money? Their function is not comparable to that of later coins.

22. Hartill, David. Cast Chinese Coins. Victoria: Trafford Publishing, 2007: 6.

23. In fact, current followers of the Austrian School continue to promote Oresme's work, such as from the Ludwig von Mises Institute (Auburn, Alabama), responsible for an edition of his treatise (Johnson, Charles. The 'De moneta' of Nicholas Oresme and English Mint Documents. Auburn: Ludwig von Mises Institute, 2009). The book description from their web page tells that: "Oresme was the first theorist to present a fully worked out ethics of money, one that shows the sheer immorality of government monopoly over money and the social effects of debasement". Mises Institute. "Books. The De Moneta of Nicholas Oresme and English Mint Documents". Mises Institute. 12 June 2016 <https://mises.org/library/ de-moneta-nicholas-oresme-and-english-mint-documents $>$; Or another example from the same origins appears in Hülsmann: nótese que Oresme dice que no fue el estado quien ordenó sabiamente la creación de monedas, sino que fueron 'los sabios' —élites naturales en una sociedad libre-quienes la crearon. Por lo tanto, ¿dónde entra en juego el estado aqui? ("Notice that he did not say that the government wisely ordained the creation of coins, but that "the sages" — natural elites in a free society-did this. So where does government come into play?"). Valín, Jorge. "Traducción de Jörg Guido Hülsmann”. Jorge Valín Weblog. 30 Maig 2004. 12 June 2016 <https://jorgevalin.wordpress.com/2004/05/30/traduccion-de-jorg-guido-hulsmann/> (Original document: Hülsmann, Jörg Guido. Nicholas Oresme and the First Monetary Treatise. Auburn: Ludwig von Mises Institute, 2004).

24. "The new, silver mono-metalist system corresponds to the economic regression culminated at this moment". Pirenne, Henri. Mahomet et Charlemagne. Paris-Brussels: Alcan-Nouvelle Société d'éditions, 1937: 221-224. In this phrase by Pirenne, read commerciale instead of économique. I do not wish to interpret or change the words of this great Belgian historian, but I understand that the sentence makes more adequate sense with the proposed change.

25. Spufford, Peter. Money and its use....

26. For example, Miguel Ángel Ladero Quesada, reviewing the lack of monetary emissions between the $9^{\text {th }}$ and $10^{\text {th }}$ centuries in Castile, states that los reyes asturianos $y$ leoneses no acuñaron moneda, por 
the rise or fall of commercial activity is usually taken as a good indicator of the growth or reduction in the use of money among the population. ${ }^{27}$

\subsubsection{Alternative theories: debt, the temple, the treasury, financing}

A variant of the commercial theory was proposed recently by David Graeber ${ }^{28}$ and received enthusiastically by some current, often self-appointed 'alternative', thinkers. ${ }^{29}$ Graeber believes that money was created from credit. He opines that before coins existed, the world was divided into debtors and creditors, and that the latter needed some sort of document when necessary to recuperate the assets they had lent. That is why money had to be invented, and, that in its beginnings, it must necessarily have been personalised and linked a specific debtor with a creditor. Graeber's theory is a variant of the earlier one by Menger that has the advantage of explaining the evolutionary process until the creation of money in detail. Like Menger's, it does not require the intervention of the state or the established power.

Another very original alternative theory is the one the makes the creation of money derive from religious practices in the temple. Richard Seaford considers that it was the necessity and pragmatism of the sanctuaries, which needed to redistribute the precious metals they received in donations to meet payments for services, that originated coins as we know them now. ${ }^{30}$ This is thus an anthropological view distanced from the commercial theory, especially in the way it defines the reason for the marks embossed on the coins. Thus, Seaford states that the stamp on the first coins was not a sign of quality (or quantity), but rather a guarantee of being refunded, and that money is accepted not only for its intrinsic value but rather for the confidence. ${ }^{31}$ I do not have elements to rebut Seaford's theory, which I believe

motivos que desconocemos suficientemente aunque deben referirse tanto a la falta de necesidad económica como al insuficiente ejercicio de sus prerrogativas políticas ("Asturian and Leonese kings did not mint coins for reasons not sufficiently known, although they must have referred to both a lack of economic necessity and the insufficient exercise of their political prerrogatives"), and adds that the commecial activities were not interupted in this period and recalls that barter was practiced in Asturias, and that in Galicia there are constant references to money in the documents. Ladero, Miguel Ángel. “Moneda y políticas monetarias...": 129-130.

27. For example, Mercedes Rueda indicates the increase in trade and the rise in population as causes of the beginning of the issue of Castilian currency in Toledo after its conquest by Alfons VI (Rueda, Mercedes. Primeras acuñaciones de Castilla y León. Salamanca: Junta de Castilla y León-Asociación Española de Aruqoelogía Medieval, 1991).

28. Graeber, David. Debt: The First 5,000 Years. Brooklyn-London: Melville House, 2010.

29. I am thinking in the Catalan case about the diffusion by Jordi Griera of the work of Agustí Chalaux defender of 'nominal money' and 'telematic money' as a response to the capitalist society we live in. Grau, Magda; Chalaux, Agustí. Assaig sobre moneda, mercat i societat, Barcelona. Barcelona: Escola Finaly, 1984; Grau, Magda; Chalaux, Agustí. Moneda telemàtica i estratègia de mercat. Barcelona: Escola Finaly, 1985.

30. Seaford, Richard. Money and the Early Greek Mind: Homer, Philosophy, Tragedy. Cambridge (UK): Cambridge University Press, 2004: 110.

31. Seaford, Richard. Money and the Early...: 136. 
should be considered plausible. However, his considerations about the marks on the first coins and confidence also make me think that it is not so far from (and could even be complementary to) the chartalist, or financial, theory presented below.

According to the chartalist theory, the state originates the money. ${ }^{32}$ This theory was first promoted by the German George Friedrich Knapp ${ }^{33}$ and later continued by the Cambridge group close to Keynes, and followers like Abba Lerner, Philip H. Wicksteed, Charles Goodhar and Alla Semenova. Nowadays, so-called chartalism constitutes one of the bases of the Modern Monetary Theory (MMT) a school of thought close to post-Keynesian economists (and here we again find the rivalry between Keynes and Hayek, and interventionism and liberalism). According to the chartalist theory, a coin has a determined value because the state determines it so, and not for anything else. More precisely still, the primordial origin and function of money had to be sought in the fact that the state produces 'tokens' that citizens coveted or found desirable to obtain because, ultimately, the state itself only accepted these tokens as a means of payment for the obligatory debt that it imposed on the inhabitants of the territories it controlled. The the role of money as a 'facilitator of trade' is later and secondary. ${ }^{34}$ Michael Crawford, the great specialist in Roman republican money, summarised the idea that money was probably invented so that official payments (taxes, pay for soldiers, tributes, etc.) could be done conveniently. In their words its creation responded to a financial reasons and that the other economic functions of money were an accidental consequence of its existence, not the reason for its creation. ${ }^{35}$

In Catalonia, Leandre Villaronga and Miquel de Crusafont have always leant towards this fiscal origin of money, but without underestimating the different commercial structures of each country. ${ }^{36}$ In contrast, the position of Fèlix Retamero, who developed some theoretical aspects of great interest in his PhD Dissertation, published in 2000, is more eclectic. For example, he criticised those who defend a unique commercial origin of money, even those authors who do not do so to camouflage it in supposed economic questions, or denounce the version of other

\footnotetext{
32. Chartalism comes from the Latin charta and refers to the official document necessary and prior to the creation of money.

33. Knapp, George Friedrich. The State Theory of Money. London: McMillan \& Co. Lted., 1929 (originally: Knapp, George Friedrich. Staatliche Theorie des Geldes. Munic: Duncker \& Humblot, 1918).

34. Hudson, Michael. "The creditary/monetary debate in historical perspective", The State, the Market and the Euro Chartalism versus Metallism in the Theory of Money, Stephanie A. Bell, Edward J. Nell, eds. Cheltenham-Northampton: Edward Elgar, 2003: 39-76; Henry, John F. "The social origins of money: The case of Egypt", Credit and State Theories of Money, L. Randall Wray, ed. Cheltenham-Northampton: Edward Elgar, 2004: 79-98; Semenova, Alla. The Origins of Money: Evaluating Chartalist and Metallist Theories in the Context of Ancient Greece and Mesopotamia. Kansas City: University of Missouri-Kansas City, 2011.

35. Crawford, Michael H. "Money and Exchange in the Roman World". Journal of Roman Studies, 60 (1970): 40-48. The spanish translation is from Leandre Villaronga: Villaronga, Leandre. "Recensiones bibliográficas". Acta Numismàtica, 2 (1972): 283.

36. Crusafont, Miquel. Història de la moneda catalana....
} 
authors who claimed that a monetary issue could happen 'spontaneously'. ${ }^{37}$ However, partially following the ideas of Christopher J. Howgego, ${ }^{38}$ the author finally decanted to consider that the two main theories about the beginnings of money (the commercial and the financial or fiscal) are true and thus, cannot be counterposed:

Que la moneda s'utilitzés per a cobrir despeses estatals ["finantial reasons"] i que, a més, intervingués en les transaccions, no tan sols és compatible, sinó que difícilment, per seguir existint com a moneda, podria ser altrament... Les dues "raons", elaborades sobre condicions inicials vertaderes, poden ser respectivament il.lustrades de manera indefinida. ${ }^{39}$

In other words, both Howgego and Retamero transfer the beginning of the invention of money to the many and differentiated existing monetary uses or circuits.

\subsubsection{The chartalist definition of money}

If I take the side of the chartalist definition of money, it is because I reject the spontaneous origins and value the political interests and their fiscal and financial necessities. From the perspective of this focus, far from commercial interests, the origin of money could have been as follows: money, an expression of political power, arose through the need to tax the population and obtain finance for the projects and targets conceived by the rulers. Money was created when the political powers decided to guarantee the exchange value of a determined object (gold and silver in Greece; bronze in China) and oblige the population to accept this. In other words, in a shortened form: money is the instrument of payment with which the political power measures the economic resources of the administration and facilitates its distribution as well as the collection of surpluses. ${ }^{40}$

Each time a government agreed on a monetary issue, it did so motivated by a specific need for financing. It was not spontaneous, nor arbitrary. Financing is

37. Retamero, Fèlix. La contínua il-lusió del moviment perpetu. La moneda dels reges, dels mulük $i$ dels seniores (segles VI-XI). Bellaterra: Universitat Autònoma de Barcelona, 2000: 82-83.

38. Howgego, Christopher. "Why did ancient states strike coins?". Numismatic Chronicle, 150 (1990): 1-26. 39. "That money was used to cover state expenses (financial reasons) and that, moreover, it intervened in the transactions, is not only compatible, but, to continue to exist as a currency, it could hardly be any different... The two "reasons", drawn up under initial true conditions, could be respectively illustrated in an undefined way". Retamero, Fèlix. La contínua il-lusió...: 84-85.

40. The classic definition of money, that I had avoided quoting until now, is the one by Isidore of Seville: In numismata tria quaeruntur: metallum, figura et pondus. Si ex iis aliquid defuerit, numisma non erit. Isidori Hispalensis. "Etymologiarum sive Originum. Liber XVI. De lapidubus et metallis. XVIII. De avro (12)". The Latin Library. 12 June 2016 < http://www.thelatinlibrary.com/isidore/16.shtml>. However, this is a strictly formal definition, not at all essential. Keeping it in mind involves dispensing with the practicality that monetary actions have always had and the consequent historical elimination of one or two (metal and weight) of the three attributes mentioned by Isidore. 
always the origin, as in the cases where a government applies a new tax to the population. One can argue more evidence of this link between power and the origin of money. The first is that the Greek word vó $\mu \iota \mu \alpha$ ("money") seems to derive from vómoৎ ("law"). It is also a good indicator that the great trading societies in Antiquity, such as the Egyptians of Phoenicians, did not have to invent money to carry out their activity. On the other hand, throughout history, mints have multiplied precisely in times of war when the military authorities require more resources to maintain the troops, and not in times of peace and economic prosperity. It is obvious that trade has been unfailingly linked to money since the latter appeared, but it would be absurd to minimise its seminal fiscal function or the financing of the public coffers. Precisely for this purpose, the making of money has always been a prerogative (a royalty) of the highest authorities, never of the traders. And when, as in the case of some local emissions of coins, when private individuals or minor authorities have used this prerogative, this has always been with the consent or delegation of the higher authority.

The type of definition of money is fundamental for proposing targets and lines of research in numismatics as an auxiliary discipline of history. For example, according to the above considerations, one cannot deduce which populations produced coins in the past from research based on those that held the most successful markets, or those that received more income from the entry of merchandise through customs. That research leads nowhere, because it was not the trade centres that minted coins, but rather the places where political power, or military power acting as political power, resides.

\subsubsection{Debate about the existence of differentiated models of money. The case of feudal money}

The debate about the existence or not of differentiated models of money according to the typology of the society that makes it and puts it into circulation is interesting. For example, in 1993, Miquel Barceló published an article with a suggestive title: Moneda fiscal i moneda feudal: una proposta de diferenciació ("Fiscal money and Feudal money a proposal for differentiation"). Barceló argued that the coinage of the Umayyad sovereigns of al-Andalus from the $8^{\text {th }}$ to the $10^{\text {th }}$ centuries offered a clear example of what he named 'fiscal money', the definition of which would be as follows:

La moneda fiscal és aquella que és batuda en règim estricte de monopoli 'legalment' fonamentat, per un Estat i és aquest mateix Estat encunyador el que l'imposa a la societat a traves d'un mecanisme consistent en les despeses estatals i la demanda de moneda, en les condicions que aquest Estat decideixi, com a pagament fiscal. ${ }^{41}$

41. "Fiscal money is that which is minted under a strict 'legally' based monopoly, by a state and it is this same minting state that imposes it on society through a mechanism consisting of state expenses and 
Later, Miquel Barceló and Fèlix Retamero developed this differentiation between fiscal money and feudal money in an article published in English: "The 'purest' feudal coin issues was, then, to create the bassis, through a curiously perverse feed-back, upon which to establish taxes on the very production of coins". ${ }^{42}$ To summarise, according to these authors, feudal money would be an artifice created to increase the income captured from the peasants; money that was produced, not with the idea of circulating it among the population and facilitating the collection of income, but more as an instrument necessary to create new taxes (tax on production, tax on the non mutation of the currency, etc.) with which to oppress the population. Another theorist who favoured the differentiation proposed by Barceló and Retamero was Michael Hendy, ${ }^{43}$ who, in turn, differentiated between 'old' money (that of the Romans) and 'new' money (from the Merovingians onwards) and indicated that the latter was characterised by allowing the participation of 'private' interests in its production. ${ }^{44}$

I consider these differentiations redundant. The supposed feudal money could not fulfil this role of propitiating new taxes if mechanisms had not previously been found that forced acceptance of this money and its later return, via taxes or monetary income, to the issuing authority. And these prior mechanisms, far from spontaneous commercial exchange, necessarily lead us to those we found mentioned in the definition of fiscal money. For the currency of feudal states, or other social groups, to occupy a subaltern position is due to a lesser degree of complexity and efficiency of the state that produces it, not to a distinct origin and use of the instrument. In my view, feudal money is also 'fiscal or financial money' in the sense Barceló granted this concept, as it fulfills the terms of the proposed definition. ${ }^{45}$

the demand for money, under the conditions this state decides, as a fiscal payment". Barceló, Miquel. "Moneda fiscal i moneda feudal: una proposta de diferenciació". Gaceta Numismática, 111 (1993): 67.

42. Barceló, Miquel; Retamero, Fèlix. "From cops to coin: which way back?". Gaceta Numismática, 12 (1996): 60; Retamero, Fèlix. La contínua il.lusió....

43. Hendy, Michael. "From Public to Private: the Western Barbarian Coinages as a Mirror of the Desintegration of Late Roman State Structures", The Economy, Fiscal Administration and Coinage of Byzantium. Northampton: Variorum Reprints, 1989: VII, 29-78.

44. One of the reasons indicated by Hendy to justify this private participation was the that he proved the proliferation of mints in the Merovingian and Carolingian epochs (Hendy, Michael. "From Public to Private...": 39,74$)$. Hendy argued that the large quantity of the issuing places was equivalent to the profusion of local political powers, as he considered them private powers.

45. Developing the line of this theory, the authors indicate the resistances to monetarisation as a characteristic element of feudal money. The resistance to monetarisation has been clearly shown by Bisson (Bisson, Thomas N. Conservation of coinage...; Bisson, Thomas N. "La monnaie fiscale: les structures régionales à l'aube de l'État medieval (1150-1250)", Rythmes de la production monétaire, de l'antiquité à nos jours: actes du colloque international organisé à Paris (du 10 au 12 janvier 1986), Georges Depeyrot, Tony Hackens, Ghislaine Moucharte, eds. Louvain-la-Neuve: Publications d'histoire de L'art et d'archéologie de l'Université Catholique de Louvain, 1987: 511-520; Bisson, Thomas N. "Els origens de l'impost sobre la moneda a Catalunya: Una reconsideració". Acta historica et archaeologica mediaevalia, 16-17 (1996): 301 310) for the Catalan counties, from the moment when the money issuing authorities established taxes, such as that one called monedatge, whose purpose was to compensate possible losses caused by a waiver on arbitrarily altering the conditions that the state imposed on the currency as payment of tax. There was resistance and pacts. Thus, the only thing this shows is that the commercial function of money was 


\subsection{Numismatic research}

\subsubsection{The primary sources: limits and problematics}

None of the three branches of numismatic research mentioned at the start of this article can do without the simultaneous study of the documentation (written or archaeological) along with the material observation of the surviving coins, identifying their marks and method of production. The connection between the two types of sources (documentation and physical coins) should provide the researcher with a more precise approach to the reality. The fact of working with only one of the two types of sources can lead to misunderstanding, because each suffers the limitations that cloud understanding of the facts presented. For example, the written document is not always effective. Many documents are full of failed intentions, although they present the likely form of a fully plausible order, sentence or disposition. And that includes first drafts, later modified in unknown terms, or firm political intentions but that were impossible to fulfil, or promises that never became reality. ${ }^{46}$ In numismatic studies based only on the written documentation, it is difficult to check the effectiveness of the monetary action extracted from the papers. For example: Was the order to produce that monetary issue carried out? Were the dispositions effective at preventing the forging and alteration of the coin, so habitual that year?

The written document can confuse us, but the physical coins trick us even more often. This is something that has gone unnoticed by many of the numismatists who have dedicated themselves to this subject. ${ }^{47}$ Without the confirmation of the written documentation we should not consider any numismatic paradigm to be an absolute certainty, however often repeated or common it is. We have learnt (or should have learnt) this prudence from the modern and contemporary issues of coins, much better documented than the ancient or medieval ones. There are very many and disturbing examples. For instance, coins minted in 1823, during the Liberal Triennium, have the date 1814; ${ }^{48}$ the silver croats minted in Barcelona in 1584 have the portrait of Ferdinand the Catholic and a regular gothic epigraph typical of the $15^{\text {th }}$ century ${ }^{49}$ the silver and billon coins in the Kingdom of Castile continued

subordinate to the fiscal function. On this question, see also the round table organised by the Laboratoire de Médiévistique occidentale de Paris - LAMOP_ (Feller, Laurent, dir. Calculs et rationalités dans la segnorie médiévale: les conversions de redevances entre $x i^{e}$ et $x v^{2}$ siècles. Paris: Publications de la Sorbonne, 2009).

46. And this still happens nowadays. An example is the motion presented to the European Parliament on the $25^{\text {th }}$ of Octuber 2005, backed by over half the Members of the European Parliament (MEP), asking the European Commission and European Central Bank to recognise the need to introduce one and two Euro notes. However, as the European Central Bank is not directly responsible to the Parliament or the Commission, it simply ignored the motion and petition.

47. This is not the case of the French manual of reference by Marc Bompaire and Françoise Dumas (Bompaire, Marc; Dumas, Françoise. Numismatique médiévale: monnaies et documents d'origine française. Turnhout: Brepols, 2000), that deals with some of these difficulties (pièges) in the depth they deserve.

48. Sanahuja, Xavier. "La seca constitucional de Barcelona (1822-1823)". Acta Numismàtica, 27 (1997): 111 .

49. Sanahuja, Xavier. “Ducats i principats catalans...": 105-133. 
to appear with the names of Isabelle and Ferdinand, the Catholic Monarchs until $1566 ;^{50}$ the local pennies of Puigcerdà minted in 1642, during the Catalan Revolt, bear the date $1576,{ }^{51}$ among others. This is the first trick, and surely the most important of all. It is the result of various causes. The first and most evident is that coins were not always produced at the same time as the dies and mints that record their imprints. Sometimes, there is enough with a lag of a few months to confuse and introduce errors into the narrative of events. When the lag is several centuries, the historiographic result can be absurd in the best of cases, or seriously wrong, in most of them. There is a second, not so evident, cause which is that it is not always interesting to record the truth (or reality) in the type and engravings on the coins produced, nor should they always change their engraving without a positive reason. Finally, a third and last cause is the conserving of types of coins for decades or even centuries to show, at first sight, that the issuing authority maintained the quality of the coin, as it had promised, without changing the slightest detail. ${ }^{52}$

A second trick is the result of not understanding that a coin not necessarily only circulated the year it was minted, and in a single territory, but also that the vicissitudes of history can have led it to circulate in centuries and geographic areas very different from those of its origins. I am not referring to accidental or residual circulation, but rather to fully legal and intentional circulation. For example, some coins struck in Castile during the $16^{\text {th }}$ century did not circulate effectively in Catalonia until $1718,{ }^{53}$ two hundred years later than would have been predicted by a stratigraphic analysis in an archaeological dig that did not take into account the circulatory vicissitudes of the physical coins.

The third deception is less important, as it is probably more easily detectable. This is the confusion provoked by those coin-like objects, such as tokens, medals or stamps, which, at a given moment, can pass as coins. In these cases, the trick can easily be avoided by accurately describing and cataloguing the authentic coins.

Finally, a fourth trick can also be avoided by accurate cataloguing and description of the legitimate coins. This is the identification of counterfeit coins, both those made to circulate in their due time and those made more recently, designed to trick collectors and scholars. ${ }^{54}$ Regarding the coins counterfeited in the times they

50. Beltrán, Antonio. “Ensayo sobre la cronología de las monedas castellanas a nombre de Fernando e Isabel". Numisma, 7 (1953): 37-56.

51. Sanahuja, Xavier. "Els menuts de Puigcerdà amb data 1576". L'Ardit, 12 (1999): 25-30.

52. Bisson, Thomas N. Conservation of coinage.....

53. On this question, see a good article by Felip Mateu Llopis (Mateu, Felip. “Les primeres encunyacions barcelonines de Felip V. Documents per a llur estudi (1704-1705)". Estudis Universitaris Catalans, 18 (1933): 92-104) and also a documentary contribution related to the process of replacing the Catalan money with Castilian in 1718 (Sanahuja, Xavier. "Barcelona, any 1718". L'Ardit, 18 (2003): 36-41).

54. See an example of the cases mentioned below in a recent work (Sanahuja, Xavier. "Las grandes falsificaciones del vellón castellano en los siglos XVI y XVII". Gaceta Numismática, 184 (2012): 15-29). Counterfeiting appears continually in the great numismatic works but specifically one should read the contribution, although mainly focussed on the modern epoch, by Albert Estrada (Estrada, Albert. La lluita contra la moneda falsa a la Barcelona de Felip II (1598-1621). Barcelona: Ajuntament de Barcelona, $2011)$. 
circulated, it must be taken into account that, as the written documents show, they were the outward sign of a widespread and ongoing phenomenon throughout the medieval, modern and contemporary epochs. Bear in mind that (nowadays, in the past and in the future) there are three types of counterfeit coins. The first type is forgeries by expert specialists, who achieve a morphological finish almost exactly like the original. ${ }^{55}$ The second type is the forgeries by skilled operators, with a good formal finish, but slightly different from the original. The third and last type is the counterfeits by non-experts, the result of which resultant is seen at a glance to be fraudulent. The numismatic researchers do not need to concern themselves much with types 1 and 3. The first type are passed as authentic and do not even usually generate doubts; the second type are easy to identify as false. The problem lies in the type-2 counterfeits, because these are well made coins that appear authentic, although different from the legal issues. When these counterfeits are abundant, it is easy for them to be considered legitimate and produced by the competent issuing authorities, thus distorting the numismatic research. To distinguish these type-2 counterfeits from the legitimate issues, the scientific method must be applied during the research. All these pieces with elements alien to the characteristics of the legitimate mint should be considered false, however well done they may seem. To establish the characteristic elements of each mint or factory, there is enough with seeing as many coins as possible. Thus, the most recurrent characteristics will be those that indicate the legitimacy of the pieces, given that, in the vast majority of cases, the production of forgeries has always been quantitatively lower than the official and legitimate output. Numismatic studies based only on observing the physical coins naturally tends towards the absurd when they attempt to go beyond the merely descriptive objectives to to try to reach higher levels of historical interpretation.

\subsubsection{Secondary sources: special difficulty}

Among the written documents, one can find specific types of sources that should be analysed with great caution. I am referring to the treatises and technical compendia on money and the narrative chronicles that contain some related episodes. I do not give much importance to this kind of source, beyond being witnesses to some specific monetary phenomena, especially because these sources tend to have drawbacks that are often repeated (and that have not always been well weighted among historians). The limitation is that the writers of treatises always tend to consider that a utopian past was always better than the present contaminated by modernity. ${ }^{56}$

55. Sometimes these expert forgeries were ordered by foreign monarchs, enemies and/or neighbours, often from the same official mints (for example, in the case documented in: Sanahuja, Xavier. "L'arrendament de les encunyacions d'or de Perpinyà a Pere Blan entre 1352 i 1365". Acta Numismàtica, 26 (1996): 147-160).

56. I have dealt with this question previously (Sanahuja, Xavier. "La moneda com a origen de crisis alimentàries?", Crisis alimenticias en la Edad Media: modelos, explicaciones y representaciones, Pere Benito, ed. 
I am not only referring to medieval or modern authors, but also contemporary writers. For example, in 1962 Cristòfol Massó Escofet defended the gold standard because he blamed the relatively recently introduced fiat money (bank notes) for inflation, both through the necessity to find an easy way for governments to wipe out their deficits, and the instability of paper on international markets (with their frequent speculative oscillations), and the excess resulting from the creation of bank credit. ${ }^{57}$ The case is paradigmatic of what we read in treatises and chronicles: the current problems are due to having abandoned ancient practices; there are no new proposals, those from the past are better (although, obviously and paradoxically, these have failed and disappeared). ${ }^{58}$ Clearly, despite the media coverage, attempts to return to the past usually end up failing, often in their early stages. It is not worth overestimating those treatise writers who, in practice, had no influence on the development of the events studied. ${ }^{59}$

It is true that it would be cheating if I did not justify my posture towards that type of sources somewhat more precisely. I shall add some brief examples. The first case

Lleida: Milenio, 2012: 221-230). When I refer to treatises, I do not mean technical manuals, dedicated to explaining mathematical or mercantile operations or the founding and alloying of metals, such as those by Andreu (Andreu, Joan [Juan Andrés]. Sumario breve de la práctica de la arithmética de todo el curso del arte mercantívol bien declarado, el cual se llama Maestro de Cuento. Valencia: Joan Jofré, 1515), Vatallol (Vatallol, Joan. Pratica mercantivol composta e ordenada per en Joan Vatallol de la ciutat de Mallorques. Palma of Majorca: Antiga Impremta Soler, facsimile 1521), Aurel (Aurel, Marc. Tratado muy útil y provechoso para toda manera de tratantes y personas aficionadas al contar; de reglas breves de reducciones de monedas y otras reglas tanto breves quanto compendiosas. Valencia: Francisco Díaz Romano, 1541), Texeda (Texeda, Gaspar de. Suma de arithmetica prática y de todas mercaderías, con la orden de contadores. Valladolid: Officina de Francisco Fernandez de Cordova, 1546), Pérez de Moya (Pérez de Moya, Juan, Manual de contadores en que se pone en suma lo que un contador ha menester saber y una orden para que los que no saben escribir con oyirlo leer, sepan contar y convertir de memoria unas monedas en otras. Con unas tablas al fin en Guarismo y Castellano: para averigüar con facilidad las cuentas de los réditos de los censos y juros, según usanza de España y otros Reynos. Va tan exemplificado que qualquiera de mediana habilidad, con poco trabajo, aprenderá a contar sin maestro. Without place of publication: without publisher, 1562), Roca (Roca, Antich. Arithmetica por Antich Roca de Gerona compuesta y de varios autores recopilada: prouechosa para todos estados de gentes. Va añadido un compendio para tener y regir los libros de cuenta, traduzido de lengua francesa en romance castellano. Barcelona: Claudio Bornat, 1564), Arfe (Arfe, Juan de [Joan Arphe]. Quilatador de la plata, oro y piedras. Valladolid: Alonso y Diego Fernández de Cordova, 1572), Eleyzalde (Eleyzalde, Miguel. Guía de los contadores donde se contienen muchas y muy provechosas reglas de cuenta, guarisma y castellana, declaradas por práctica muy fácil de entender con muchos exemplos muy necesarios, con el valor de las monedas de España y de los demás reynos della. Madrid: Pierres Cosin, 1579) or Cortés (Cortés, Jerónimo [Jeroni]. Compendio de reglas breves, con el arte de hallarlas e inventarlas, assí para las reductiones de monedas del Reyno de Valencia, Aragón, Barcelona y Castilla, como para las demás monedas de los otros reynos, muy útil y necesario a todo género de tratantes, con muchas preguntas y respuestas de números. Valencia: Herederos de Ioan Navarro, 1594), but rather the ideologically active works that reflect on the concept and utility of money in society.

57. Massó, Cristòfol. Inflació monetària. Barcelona: Rafael Dalmau, 1962.

58. And it still happens nowadays: during the economic crisis that began in 2008 in Catalonia and Europe, political positions of the far left and far right on the Continent coincided in calling for the end of the Euro as the single currency and a return to the state currencies.

59. From the research by Sargent and Velde (Sargent, Thomas. J.; Velde, François R. The Big Problem of Small Change. Princeton: Princeton University Press, 2002) one notices an evolution of monetary treatises in Europe from medieval times to the present that confirms the constant failure of wanting to return to the past. 
is that of Arnau de Capdevila, author of a treatise in 1437, frequently quoted in all the historiographic works on Catalan money. ${ }^{60}$ In other more tangible questions, Capdevila complained that one of the ills of the $15^{\text {th }}$ century Catalan currency was having abandoned the fair relation between the intrinsic value and circulatory value of the coins. On that occasion, part of his recipe was applied in various phases during the second half of the $15^{\text {th }}$ century, but the definitive step, which consisted of projecting and making coins that respected the fair intrinsic value of their value circulatory, did not go beyond being only a test. It is true that the test went very far, having even earned royal permission, and having decided the coin denominations of new creation in circulation. However, when it came to applying it, they were unable to do so. The numbers did not add up, it was not realistic. A second example proposed is that of the Muslim chronicler Al-Maqrizi (1364-1442), from whom we learn about the famine in contemporary Mamluk Egypt. ${ }^{61}$ Al-Maqrizi explained that the food crisis in his time was caused by inept government, political corruption, and also natural causes like the lesser flooding of the River Nile. However, he emphasises that the monetary crisis was one of the causes of the famine. Regarding monetary policy, like so many others, Al-Maqrizi was a nostalgic utopian who preached a return to the Umayyad Damascus of 696. The only problem is that he lived around 1400 and in an Egypt made up of other Muslim and Christian estates in developed commercials networks. Thus, Al-Maqrizi accused the recent fiat money, introduced a few years earlier, of being the main cause of inflation and the monetary crisis, at the same time, he harked after the coins he believed were truly useful for setting the prices of things, namely gold and silver coins. More specifically, he believed that the new fiat money, of pure copper, created with bad speculative intentions, pushed prices upwards and lowered the purchasing power of the people. However, he based this latter belief on some unfortunate examples. Thus, Al-Maqrizi was hurt that a

60. In fact, Arnau de Capdevilla was the author of two treatises about money in 1437. These are: Tractac é compendi fet de les monedes per lo qual pot esser mes é comprès com un regne ó pàtria pot esser robat é gastat per art de billoneria, é axi mateix com ne pot ésser preservat si diligentment es advertit, attès ó entès (20 ${ }^{\text {th }}$ March) and Lo present tractac é compendi es de matèria de monedas en lo qual és mostrat que més val bona moneda que falça, é lo billoner quina art té de tràurer la bona moneda de la flaca moneda; é fonch fet é ordenat a XV del mes de juliol del any de la nativitat del nostre mсCCCXXXVII (14 ${ }^{\text {th }}$ July) (Zulaica, Fernando. "Propuesta para reorganizar el sistema monetario en Cataluña: el 'Tractat e compendi' de Arnau de Capdevila", Actas del VII Congreso de la Asociación de Historia Económica. (Zaragoza, 19-21 de septiembre de 2001). Saragossa: Universidad de Zaragoza, 2001: 2-3).

61. His book Eghathat Al Omma be Kashf Al Ghomma ("about the famines that took place in Egypt"), studied by Josep Maria Salrach (Salrach, Josep Maria. La fam al món. Passat i present. Vic: Eumo, 2009), serves to summarise the question of what factors cause or increase shortages or famine at a certain time. This question has provoked many hypotheses over time, and these have traditionally been related to those processes that intervene in a context of a decline in the availability of food (a context known by the acronym FAD). However, an FAD context does not explain why only part of the population is exposed to famine or shortages, while another part is not. To respond to this anomaly, economists and historians have indicated new explanations based on an alternative context of a decline in the options of access to food (context known as FED). In an FED context, the options of having access to food, likewise the money to buy it with and the transport to reach it, fall sharply in a more or less imprtant part of a territory. Within the set of FED processes there is also the currency, although surely in an ill-considered way (Sanahuja, Xavier. "La moneda com a origen de crisis....": 221-230). 
capital of 1,000 dirhams from before in pieces of silver was worth over 3,000 dirhams from after in pieces of copper. The author's example is compatible with a nominal rise in prices but in no way serves to show a decline in the purchasing power of the population. This resort to fiat money was pioneering in the $15^{\text {th }}$ century and indicated the same path that all other countries in the world would have to follow some time or another in their history due to the need to increase the use of money in people's everyday activities. ${ }^{62}$

A final comment refers to the compilations, chronicles and short chronicles that can be used in a timely manner exclusively to point out the existence of a specific monetary phenomenon. Great care must be taken with this type of written source; many of them are full of errors, both of interpretation and transcription. Maybe I can be blamed for excessive generalization on this issue, but my immersion in such sources has shown me a panorama full of imperfections. For example, in Catalonia, in the period studied, the compendium that has more monetary mentions is the socalled Rúbriques de Bruniquer. ${ }^{63}$ However, it is full of inaccuracies that have become visible nowadays thanks to the publication of one of its parts corresponding to the Catalan Revolt. ${ }^{64}$ Effectively, many of the monetary rubrics referring to that epoch have the wrong date and even the wrong month. ${ }^{65}$ We know this because the original municipal agreements in the records of the Barcelona Council have survived and it has been possible to compare the veracity, for example, of the precise dating of the facts mentioned. And regarding the chronicles of records and memoires, the credibility seems yet more questionable to me. Even some authors who wrote about what happened some years previously, when they were younger, appear not to recall absolutely anything like what probably happened. ${ }^{66} \mathrm{~A}$ paradigmatic case is Vicencio Juan de Lastanosa. ${ }^{67}$ During his lifetime, he published his Tratado, which mainly consisted in the study of the coins conserved in his times, with the addition of the reading of some written documents. What is surprising about Lastanosa is that, on

62. Regarding Al-Maqrizi and the food crisis described, it is not a question of stating that there was no monetary crisis related to the food crisis, but rather that the former could have been a consequence rather than a cause of the latter. In any case, the return to the Umayyad origins the writer called for could not be a future solution for the problems of Egypt in the $15^{\text {th }}$ century.

63. Rubriques de Bruniquer. Cerimonial dels magnífichs consellers y regiment de la ciutat de Barcelona, ed. Francesc Carreras i Candi, Bartomeu Gunyalons. Barcelona: Impremta d'Henrich, 1912-1916 (5 volumes).

64. Crusafont, Miquel. Història de la moneda de la guerra dels Segadors (Primera República Catalana). Barcelona: Societat Catalana d'Estudis Numismàtics, 2001.

65. However, and by error, many of the incorrect rubrics were also included, duplicated, in the documentary corpus of this work.

66. This difficulty is not only inherent to previous characters. How many people who experienced similar events would remember them today? I do not have the answer but I imagine it, extrapolating it from the responses that Antoni Turró obtained in the 1960s (Turró, Antoni. Les emissions monetàries oficials de la guerra Civil (1936-1939). I: Andorra, Illes Balears i Catalunya (Generalitat i locals). Barcelona: Societat Catalana d'Estudis Numismàtics, 2007) when he asked the people of a certain place if they remembered the issues of municipal money in 1937, generalised all over Catalonia.

67. Lastanosa, Vicencio Juan. Tratado de la moneda jaquesa. Saragossa: without publisher, 1681 (Reprinted: Valencia: Librerías París-Valencia, 1987). 
dealing with various aspects from his time, we learn of things that are impossible. ${ }^{68}$ For example, he writes that during the reign of Phillip III (IV) (during his life) two similar types of small coins were in circulation in Aragon but with different weight (10.50 and 21 grains). However, the documents and surviving coins dismiss this fact. It is true that the errors come from having written the compilations, reports or chronicles at a distant time. This distance is sometimes moderate, as we have seen in Lastanosa's case, but more than enough to distort the facts. In contrast, the same does not happen with the dietaries, that are written at the time (although not always) and should thus be considered free from inaccuracies beyond those of interpretation. ${ }^{69}$

\subsubsection{The credit of numismatic studies}

The research into money has traditionally been done by a small group of specialists. Specialisation in any field of history tends to convert the researcher into a figure of reference from whom general works are built up. However, when the group of specialists in a specific theme is too small, and that is what happens in numismatics, a paradoxical phenomenon occurs: the advances achieved by these specialists are certainly the only ones that can be accepted as a paradigm, but, at the same time, they are examined with reticence and are often not incorporated scientifically until a lot later. The reticence is due to the insecurity of knowing whether the quality of the limited number of specialists is high enough. This precaution should not be criticised. Some unquestionable truths, which everyone has accepted without asking about their veracity, have turned out to be false. Josep Salat himself, the first of the modern Catalan numismatists, was aware of this difficulty and expressed it as follows:

Cuando se habla de noticias históricas y poco conocidas (como es la numismática catalana), es preciso presentar documentos auténticos, para que las noticias tengan autoridad y peso; porqué en estas y otras materias sucede, que algunos lectores creen lo que se les dice, y otros suspenden el asenso. Nadie debe agraviarse de que se juzgue asi, porqué una infinidad de noticias históricas que años atrás se tenían por verdaderas, en el dia no se han hallado tales, y apuradas y examinadas á la luz de la buena crítica, han resultado fabulosas. ${ }^{70}$

68. Sanahuja, Xavier. “Reconsideración de la moneda jaquesa de vellón de época moderna (1519-1717)”. Numisma, 247 (2003): 87-104.

69. In Catalonia, it is the case of the Manual dels Novells Ardits (Manual de novells Ardits, vulgarment apellat Dietari de l'Antich Consell barceloní. Barcelona: Impremta d'Henrich, 1892-1975, 28 volumes), of the Dietaris of the Generalitat de Catalunya (Sans Travé, Josep Maria, dir. Dietaris de la Generalitat de Catalunya. Volum I. Anys 1411 a 1539. Barcelona: Generalitat de Catalunya, 1994; Sans Travé, Josep Maria, dir. Dietaris de la Generalitat de Catalunya. Volum II. Anys 1539 a 1578. Barcelona: Generalitat de Catalunya, 1994; Sans Travé, Josep Maria, dir. Dietaris de la Generalitat de Catalunya. Volum III. Anys 1578 a 1611. Barcelona: Generalitat de Catalunya, 1996) or the Dietari de la fidelíssima vila de Puigcerdà (Galceran, Salvador. Dietari de la fidelíssima vila de Puigcerdà. Barcelona: Fundació Salvador Vives Casajuana, 1977).

70. "When one talks of historical and little known news (as is Catalan numismatics), it is necessary to present authentic documents, so the news has authority and weight; because in these and other subjects, 
Prudence when accepting new numismatic contributions means demanding the verification of the leading numismatic entities in each country, especially of those that publish scientifically demanding books and journals. ${ }^{71}$

\section{The three branches of numismatics. Summary of the evolution over the last 100 years}

During the evolution of numismatics, the branch dedicated to explaining the origin, evolution and importance of money in society has been the slowest to appear. Despite that, it should be placed in first position for having become the most essential and influential in the current historical discourse. It is also the most easily influenced of the three branches given the various theories about the origin of money mentioned above.

\subsection{First branch: The history of money (and the impact of the work of Peter Spufford)}

In this branch, it is not so important to have a numismatic corpus of conserved coins or be able to precisely identify a specific example. It is more satisfactory to know the evolution of the monetary systems and their relation to such human activities as trade, savings, financing, credit or taxation. In contrast with the first branch, the supporters of this second one have often fled from the term 'numismatics', even feeling ashamed of it, as they consider it equivalent to a descriptive activity, not very useful and closed off from the desirable progress of the historical paradigm. Its followers have preferred to use the denominations like 'history of money' (always in singular) or 'history of the coin'. The change of orientation promoted by this second branch is perceptible in all fields related to numismatics. For example, public coin collections had been gathered in the $19^{\text {th }}$ century in the form of numismatic cabinets, in places half way between museums and between stores that met the requirements the scholars studying coins demand: in other words, these cabinets were real archives devoted to protect and receive numismatic sources. Today, on distancing ourselves from the material study of the coins, these have ceased to be mass-produced historical documents

\footnotetext{
it happens that some readers believe what they are told, and others suspend their assent. No one should feel wronged to be judged thus, because an infinity of historical news that years ago was considered true, in the [latter] day have been found not to be so, and worked on and examined in the light of good criticism, have been shown to be fables". Salat, Josep. Tratado de las monedas labradas en el Principado de Cataluña, con documentos justificativos. Barcelona: Antoni Brusi, 1818: II, III (republished: Madrid: J. R. Cayón, 1982).

71. Examples include the cases of the Societat Catalana d'Estudis Numismàtics in Catalonia, the Sociedad Iberoamericana de Estudios Numismáticos in Spain, the Société Française de Numismatique and Société d'Études Numismatiques et Archéologiques in France, the British Royal Numismatic Society in England, etc.
} 
to become singular priceless treasures. Being less known, they are consequently more sacralised. Instead of being in historical archives, the coins are kept in the so-called 'money museums' or even in the corresponding sections of the art museums. ${ }^{72}$

A large part of the success of this branch must be sought in the participation of internationally renowned historians. Thus, for instance, Henri Pirenne and Marc Bloch, ${ }^{73}$ two of the $20^{\text {th }}$ century's great historians, realised the historical importance of money and turned it into a subject of study or, at least, of consideration and respect. Bloch, for example, stated that monetary phenomena dominate economic life and that they are at the same time un symptome et un effet, ${ }^{74}$ making it understood that sometimes the monetary questions detected by historians can be symptoms of an economic situation (defined by such other factors as demography, politics, etc.), but that other times, these monetary questions can be the trigger, the disruptors of the conjuncture. Since then, the monetary element has been considered a factor to be assessed in depth in any work on economic history.

However, most authors who have dealt with these themes have always chosen the same path: to consider that the history of money is the same as the history of trade, and that money works based on two axes: the consuming household and the producing company. ${ }^{75}$ This focus, called monetarism, tends to underestimate the role of the state in monetary questions.

Outstanding among the studies dedicated to the history of money is the one by Peter Spufford (born in Hutton, Great Britain, 1934), ${ }^{76}$ professor at Cambridge until 2001 and considered literally the author of the "definitive studies of money in the Middle Ages". ${ }^{77}$ His influence has certainly been enormous among all European academic sectors. His main work is Money and its use in Medieval Europe, extensively and profusely documented, published in Cambridge in 1988, and quickly translated into Spanish (Dinero y moneda en la Europa medieval) and other European languages. So, it is inevitable to dedicate some paragraphs to him.

Spufford's main monetarist principal consists of relating the increase in the monetary mass in Europe (and thus the rise in its use) with the discovery of new mines of precious metals and the growth in trade activities. For example, regarding the Late-Roman epoch and the Germanic kingdoms, Spufford place doubts on the

72. For example, in Catalonia, the Gabinet Numismàtic de Catalunya is nowadays a section of the Museu Nacional d'Art de Catalunya and not, for example, part of the Arxiu Històric Nacional or the Museu d'Història de Catalunya.

73. Pirenne, Henri. Mahomet et Charlemagne. Paris-Brussels: Alcan-Nouvelle Société d'éditions, 1937; Bloch, Marc. "Le problème de l'or au Moyen Âge". Annales, 19 (1933): 1-32; Bloch, Marc. Esquisse d'une histoire monetaire de l'Europe. Paris: Armand Colin, 1954.

74. “a symptom and an effect". Bloch, Marc. Esquisse d'une histoire...: 7.

75. Nitsche, Roland. Money. London-New York: Collins-McGraw-Hill, 1970. In Spanish: Nitsche, Roland. El dinero. Barcelona-Madrid: Noguer S. A., 1971.

76. Spufford, Peter. Money and its use....

77. Goodreads. "Peter Spufford". Goodreads. 12 June 2016 <http://www.goodreads.com/author/ show/378972.Peter_Spufford>. It also appears in this way in other online bookshops like Amazon, Abebooks, Fishpond, etc. 
sharp break in monetary circulation in the West, according to his argument, so as not to have to doubt about the sharp drop in contemporary commercial activity. ${ }^{78}$ Curiously, however, he accepts this rupture in circulation in the case of England. ${ }^{79}$ Or for example, referring to the $12^{\text {th }}$ century, Spufford states textually, "a great increase in the amount minted was the most obvious consequence of the vast quantities of new silver being mined in Europe from 1160 s onwards" ${ }^{80}$ In other words, the increase in the use of money was due to the finding and working of new metal deposits. Spufford manages to overcome the hurdles he finds thanks to a clever use of language. For instance, regarding the increase in the monetary denominations in circulation in the Late Middle Ages, he states that,

the transformation from a currency consisting of a single denomination to one consisting of a multiplicity of denominations was the natural corollary to the extreme complexity of urban transactions that developed over the thirteenth century. ${ }^{81}$

The key word in Spufford's sentence is 'transactions', used because he considers that trade is the main factor in history. In a chartalist or fiscalist view of monetary evolution, the word 'transactions' should be replaced by 'obligations'. Spufford gives the maximum importance to trade. For example, when talking about the cases of frequent renewal of the currency by some medieval authorities, he recognises first that these authorities had to be strong enough and dominant enough in their territory, but then justifies the practice of renovation through the existence or not of commercial possibilities in the territory affected, without taking into consideration the financial needs (wars, projects, concessions of privileges) of the issuing authorities:

In general frequent coinage renewal depended on a relatively strong central authority, a developing market structure (there were perhaps as many as a hundred weekly markets in $12^{\text {th }}$ century Poland, etc. ${ }^{82}$

In summary, throughout his work, Spufford continues a process, of a monetarist nature, of this type:

1. New deposits of metal are discovered and worked

2. More coins are produced with the new metal

78. Spufford, Peter. Money and its use...: 22.

79. The rupture in the Iberian Peninsula is very evident (Metcalf, David M. "The coinage of the first and second suevic kingdoms: from Romanitas to Latinization", Galicia: da romanidade a xermanización: problemas históricos e culturais. Actas do encontro científico en homenaxe a Fermin Bouza Brey. Santiago de Compostela: Museo do Pobo Galego, 1992: 358-359; Pliego, Ruth. La moneda visigoda. Seville: Universidad de Sevilla, 2009: I, 75-79).

80. Spufford, Peter. Money and its use...: 187.

81. Spufford, Peter. Money and its use...: 239.

82. Spufford, Peter. "Local coins, and Foreign coins in Late Medieval Europe", XII Internationaler Numismatischer Kongress (Berlin, 1997), Bernd Kluge, Bernhard Weisser, eds. Berlin: Staatliche Museen, 2000: 329. 
3. The rise in the monetary mass leads to an increase in the number of commercial transactions

4. The growth of trade increases the demand for coins in different denominations

5. New metal deposits are discovered and exploited

6. Etc.

In other words, the use of money increases because new silver mines appear and because trade grows, but nowhere does he relate this increase with a specific political will. In this scheme, the author includes the progressive transfer, between the $12^{\text {th }}$ and $13^{\text {th }}$ centuries, of seigniorial incomes paid in kind towards incomes demanded in money but, curiously, does not realise the contradiction inherent in this move. Spufford collects the views of other authors, ${ }^{83}$ and realises that, from a given moment, demand for income in money was a great burden on the families, forced to resort to the market to find money and be able to meet the seigniorial demands. ${ }^{84}$ The contradiction lies in the fact that this process, the need for money, would date from before the obligation to resort to the market and, thus, completely reverse the scheme sustained throughout the book. Without realising the contradiction, Spufford moves on in time to conclude that, in the end, the increase in the monetary mass was the phenomenon that allowed the consolidation, growth and modernisation of states. He himself presented an example of the opposite case, which is when the lack of cash hinders the consolidation of strong power, by taking the case of the implementation feudalism: "The genesis behind the feudal organisation lies in the lack of gold coinage in the hands of the seventh-century Frankish kings, and the impossibility of continuing to pay the armies with coins". ${ }^{85}$

Thus, regarding the relation between money and consolidation of the institutions, Spufford's process is:

1. Increase in the monetary mass

2. The governments benefit and consolidate their power

3. Increase in the monetary mass

4. Etc.

Backwards, the monetary mass declines and the governments lose power. This is just the opposite of what is stated in the chartalist theory, according to which it is the actions of the governments that affect the increase or decrease in the monetary mass.

Another interesting aspect among those analysed by Spufford is when, where and why some European states began to a strike fiat money or coinage without intrinsic value, of pure copper:

It is not surprising that it was at Venice, the greatest commercial city in Europe, that the striking of copper coins [in 1463], should have first been discussed, for throughout

83. Like, for example, Marc Bloch (Bloch, Marc. Les caractères originaux de l'histoire rurale française. Paris: Librairie Armand Colin, 1931), Robert Fossier (Fossier, Robert. Les terres et les hommes en Picardie jusqu'à la fin du xiiie siècle. Paris-Leuven: Nauwelaerts, 1968), or Pierre Toubert (Toubert, Pierre. Les structures du Latium médieval. Le Latium méridional et la Sabine du IXe à la fin du XIIe siècle. Rome: Bibiliothèque des Écoles Françaises d'Athènes et de Rome, 1973).

84. Spufford, Peter. Money and its use...: 313-317.

85. Spufford, Peter. "Local coins, and Foreign coins...": 30. 
the second half of the fifteenth century Venice was the major European centre for the growing trade in the copper of the Alps and Carpathians, until it was supplanted by Antwerp in the first decade of the sixteenth century. It is, however, rather surprising that it was in Naples that the idea actually became a reality. It was in Naples, possibly already the largest capital city in Europe, that the first copper coins, cavalli, were struck in 1472. Once again it was clearly a matter of free choice and not of necessity, for quite enough silver existed in southern Italy at this time to mint traditional black money ${ }^{86}$

Aside from the omission of the issues of reais and ceitils of pure copper that started in Portugal at least in the reign of Edward (1433-1438), ${ }^{87}$ Spufford soon finds an explanation for the appearance of copper coins in Venice and points out that this was the greatest trading city in Europe and a centre for the trade in copper. However, in contrast, he offers no such justification for those from Naples, the need for which he indicates was unnecessary, because there was enough silver not to have had to dispense with it, and that is was a free choice, shall we say chance, casual or arbitrary. ${ }^{88}$ Throughout his work, Spufford prioritises commercial or metallurgic explanations, but these cannot always offer coherent responses for a determined phenomenon.

The Spufford paradigm seems unchangeable among historians of money or coinage. ${ }^{89}$ An example chosen at random is a summary of the history of money promoted by the British Museum, where Catherine Eagleton and Jonathan Williams state that in $10^{\text {th }}$ and $11^{\text {th }}$ centuries the use and volume of money and the speed of circulation increased. They argue that, although the revitalised Viking activity played a role in these, this expansion was mainly based on new renewable supplies of silver and the growth of local and international trade, exemplified by important fairs like the ones in Champagne. ${ }^{90}$

A second example by the same authors relates to the $16^{\text {th }}$ century and the wellknown trade deficit of the Hispanic kingdoms, and shows how easily they disassociate the monetary phenomena from contemporary political actions. Eagleton and Williams head the chapter dedicated to the modern era with this fragment from Martín González de Cellórigo:

86. Spufford, Peter. "Local coins, and Foreign coins...": 372.

87. Aragão, Augusto Carlos Teixeira de. Descripção geral e historica das moedas cinhadas en nome dos reis, regentes e governadores de Portugal. Lisbon: Imprensa Nacional, 1874: I, 218; Grierson, Philip. Coins of Medieval Europe. London: Seaby, 1991: 191 (this is an evolved version of an earlier work: Grierson, Philip. Monnaies du moyen Age. Fribourg: Office du Livre, 1976).

88. Lucia Travaini believes that the start of issues in pure copper in Naples was because the master of the mint was from Ragusa (Dubrovnik), a city where copper coins had been made for local use since 1281: oltre che per i conttati diretti, anche per l'esperienza portata del maestro della zecca Cotrugli raguseo ("as well as through direct contacts, but also through Benedetto Cotrugli's knowledge, mint-chef from Ragusa") (Travaini, Lucia. "Il ruolo di Ragusa-Dubrovnik nella creazione delle prime monete di rame a Napoli e Venezia nel Quattrocento", 'Puer Apuliae'. Mélanges offerts a Jean-Marie Martin, Errico Cuozzo, Vincent Déroche, Annick Peters-Custot, Vivien Prigent, eds. Paris: Centre de Recherche d'histoire et civilisation de Byzance, 2008: 735).

89. For example: Day, John. Monnaies et marchés au Moyen Age. Paris: Imprimerie Nationale, 1994; Derville, Alain. L'économie française au Moyen Age. Paris: Ophrys, 1995; Contamine, Philippe; Bompaire, Marc; Lebecq, Stéphane; Sarrazin, Jean-Luc. L'économie médiévale. Paris: Armand Colin, 1993; Rodamilans, Fernando. "La moneda y el sistema monetario en la Castilla medieval". Ab Initio (2010): 22-83.

90. Eagleton, Catherine; Williams, Jonathan. Money a History...: 73. 
La causa de la ruina de España es que las riquezas se las lleva el viento, y siempre han cabalgado en él en la forma de escrituras contractuales, de letras de cambio, de plata y oro, en vez de bienes que puedan producir frutos y que, a causa de su mayor valor, atraen a los ricos de otras partes $y$ así arruinan a nuestros habitantes. Por eso vemos que la razón por la falta de dinero de oro y plata en España es que hay demasiado del mismo y España es pobre porqué es rica. ${ }^{91}$

In other words, the authors take as their own a fragment that justifies the impoverishment of the modern Castilian crown through the activity of foreign speculators and not, shall we say, through an absurd policy of the monarchy of undertaking very expensive and not very productive enterprises, or due to suffering a foreign trade deficit. ${ }^{92}$

Even Jacques Le Goff, in a recent work, insisted on trade as the mover for the monetary evolution of western society. ${ }^{93}$ Like Spufford, Le Goff signals a great monetary change in the $13^{\text {th }}$ century but, far from linking this to the development of states, he makes it precede this development:

C'est un tournant général de la chrétienté qui se retrouve dans le domaine monétaire. Les principaux signes sont, tout d'abord, la reprise de la frappe de l'or, et donc le retour au bimétallisme orlargent. Ensuite, on constate un développement du commerce, qui utilise essentiellement le monnayage d'argent. Enfin on constate un retour à l'État.... ${ }^{94}$

In other words, the role of the state as the promoter of the use of money moves into third place, minimised by the impact of the growth in trade and even the anonymous and spontaneous minting of gold coins. It is still worth emphasising another fragment from Le Goff, transcribed below. Like the above, it is the response to a question by Bruno Collin:

BC: Au xIII siècle, vous scindez l'usage de l'argent en trois parties essentielles.

JLG: Oui. Le premier vise à l'acquisition de terres. Le second au souci de sécurité avec le financement des murailles de protection des villes. Et enfin, des ouevres pieuses. Cette periode est, d'ailleurs, marquée par l'apparition des ordres mendiants. Le terme signifie que ces gens vont vivre grâce a l'aumône dont ils vont utiliser une partie afin de soulager la population

91. "The reason for the ruin of Spain is the riches that went with the wind, and that have always ridden on it in the form of contractual writings, bills of exchange, silver and gold, instead of goods that can bear fruit and which, because of their greater value, attract the rich from elsewhere and thus ruin to our inhabitants. That is why we see that the reason for the lack of gold and silver money in Spain is that there is too much of it and Spain is poor because it is rich". Eagleton, Catherine; Williams, Jonathan. Money a History...: 162. Quoted words are from: González de Cellorigo, Martín. Memorial de la política necesaria y útil restauración a la república de España. Madrid: Instituto de Estudios Fiscales, 1992.

92. As has been defended for some time by authors such as John H. Elliott (Elliott, John Huxtable. Imperial Spain, 1469-1716. London: Edward Arnold, 1963).

93. Le Goff, Jacques. Le Moyen Âge et l'argent. Paris: Perrin, 2010.

94. "It is a general turning point of Christendom that is found in the monetary domain. The main signs are, first of all, the resumption of the striking of gold, and therefore the return to gold/silver bimetallism. Then there is a development of trade, which essentially uses the silver coinage. Finally we see a return to the state...". Collin, Bruno. "Interview de Jacques Le Goff". Numismatique et change, 418 (2010): 24-25. 
pauvre. En compensation de l'enrichessement de certaines classes de la société, l'église exigera d'elles la bienfaisance, essentiellement sous forme monétaire. Ce qui correspon à l'apparition de la 'monnaie noire' en billon qui est precisément celle de l'aumône. C'est aussi celle de la vie quotidienne en milieu rural...95

Leaving aside the triad explanation, which we should take as a clever game and not a serious reflection, ${ }^{96}$ Le Goff rounds off and closes Spufford's schemes. The growth of trade cannot explain in itself the growing necessity and production of minor currency, and so the octogenarian medievalist offers us a response that is both novelistic and disconcerting: that black money, made of debased metal and little value, served for alms and charity or to circulate in the rural environment. ${ }^{97}$

To close this section I wish to reflect on another phenomenon that can be detected: the formula 'money=trade', repeated so many times among historians of money, is not reciprocal when the factors are altered. Trade historians do not necessarily have to resort to money to explain the evolution of the subject of their study. I will restrict myself to presenting two examples from two significant authors, one from before Spufford's work, Robert S. Lopez, and the other later, Michael McCormick.

In his work The Commercial Revolution of the Middle Ages, ${ }^{98}$ Robert Sabatino Lopez began by recognising the importance of coins during his research, but only as a documentary support. He says that coins, as they are mentioned in the documents or conserved materially in the collections, constitute the most accessible means to take the pulse of the early phases of the commercial revolution. For example, Lopez realizes through the coinages study that in all Catholic Europe, and even more clearly in Italy, the long deflationary tendency of the Early Middle Ages was reversed..$^{99}$ However, he then added that the force behind the commercial revolution had to be sought in other innovations beyond the increase of monetary mass. In other words the supply of minted metal never met demand and the credit, finally available in abundance, was the true grease for the mechanism of the commercial revolution. ${ }^{100}$

95. "BC: In the thirteenth century, you split the use of money into three essential parts. JLG: Yes. The first concerns the acquisition of land. The second concerned with security with the financing of the walls to protect the cities. And finally, pious works. This period is, moreover, marked by the appearance of mendicant orders. The term means that these people live thanks to the alms which they use a part in order to relieve the poor population. As compensation for the enrichment of certain classes of society, the church requires charity, mainly in monetary form. This corresponds to the appearance of the 'black money' in billon, which is precisely that of alms. It is also that of everyday life in rural areas...". Collin, Bruno. "Interview de Jacques Le Goff". Numismatique et change, 418 (2010): 24-25.

96. I prefer to believe that it is a divertimento of the author and that he does not take it too seriously. The relation is very clear: buy land=the peasant, build walls=the soldier, do alms=the monk; or if one prefers: Duby, George. The Three Orders: Feudal Society Imagined. Chicago: University of Chicago Press, 1981.

97. When in fact small coins circulated (and circulate) preferably within the cities, which is where they were needed to pay small taxes, tolls and as change in the retail trade.

98. Lopez, Roberto S. La revolución comercial en la Europa Medieval. Barcelona: El Albir, 1981. Spanish translation of the original text (in English): Lopez, Roberto Sabatino. The commercial Revolution of the Middle Ages. Englewood Cliffs: Prentice Hall, 1971.

99. Lopez, Roberto S. La revolución comercial...: 112.

100. Lopez, Roberto S. La revolución comercial...: 113-115. 
Lopez ended up deducing that the speed of monetary circulation increased faster than the volume of goods and services. ${ }^{101}$ Thus, the commercial revolution did not begin with monetary phenomena, but through new mercantile practices (expansion of credit, new instruments like the bill of exchange, insurances, etc.), while the parallel issue of coins of ever decreasing intrinsic content was due to other causes not related to the commercial revolution, such as (and I add this) greater trust by the user in the issuing power of the coin and also a growing need for small change to deal with small everyday obligations (not necessarily transactions).

Another, more recent, example of this paradox of the non-reciprocity of the formula

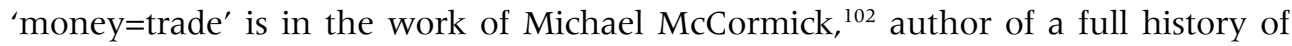
late-medieval European trade: Origins of the European Economy. He dedicates a whole section to talking about coins, but not in the sense we read in Spufford. McCormick is only interested in listing the findings of coins from the epoch studied, obviously well identified, to be able to show the relations between some territories and others. Thus, McCormick shows us that it is possible to do a monograph on trade from the $6^{\text {th }}$ to the $10^{\text {th }}$ centuries, for instance, without talking about the money except when identifying the findings of Muslim, Byzantine and Carolingian coins, to be able to prove the presence of merchants from these territories in a specific place. McCormick deals with the coins only as merchandise, or as documentary proof of some relevant event, but not, for example, as reactivators of trade. Trade flows through his work without the need for coins.

Thomas J. Sargent and François R. Velde surprised the academic world with a study of small change (The Big Problem of Small Change) that dispensed with trade as a revolutionary factor. ${ }^{103}$ Sargent and Velde analysed the problem of the recurring crises of small change (of lack or excess) in circulation throughout history. The interpretation they offer about the function of money in the medieval and modern epochs is very interesting. For instance, they explain that the late medieval governments (they do not distinguish between feudal lords, caliphs or emperors) did not think of money as a means of exchange (or of trade) but rather as a merchandise of silver with a determined value. This consideration meant that any form of circulating money had to have a stable exchange rate according to their content and, as that was not always possible, it caused recurrent shortages of small change. Cipolla, who inspired the title of the work by Sargent and Velde, proposed that the solution to the crisis of small change should be sought with the making of substitutory tokens, backed by the government, who would have to be prepared to exchange them for good coins of a higher value. Sargent and Velde added two conditions, these being that the number of these tokens produced should not be too small (to be able to facilitate change) nor too large (to avoid generating inflation). ${ }^{104}$

101. Lopez, Roberto S. La revolución comercial...: 114.

102. McCormick, Michael. Orígenes de la economía europea. Viajeros y comerciantes en la Alta Edad Media. Barcelona: Crítica, 2005 (Spanish version of the original text in English: McCormick, Michael. Origins of the European Economy. Cambridge (UK): Cambridge University Press, 2001).

103. Sargent, Thomas. J.; Velde, François R. The Big Problem....

104. Sargent, Thomas. J.; Velde, François R. The Big Problem...: 4-6. 
The process of building and implementing Sargent and Velde's formula also explains the evolution of European monetary experiments from the medieval epoch to the $20^{\text {th }}$ century and which, in a very summarised, but continuous, sequence can be established as follows: ${ }^{105}$

Table 1. Evolution of European coinages from Medieval Ages to 20th Century

\begin{tabular}{|l|}
\hline \multicolumn{1}{|c|}{\begin{tabular}{c|} 
INITIAL PHASE: \\
coins with intrinsic value
\end{tabular}} \\
\hline 1.- Silver \\
\hline 2.- Silver and billon \\
\hline 3.- Gold, silver and billon \\
\hline
\end{tabular}

\begin{tabular}{|l|}
\hline \multicolumn{1}{|c|}{$\begin{array}{c}\text { INTERMEDIATE PHASE: } \\
\text { intrinsically valueless of small change }\end{array}$} \\
\hline 4.- Gold, silver and poor billon \\
\hline 5.- Gold, silver and copper (or tin) \\
\hline 6.- Official gold, and silver, copper and private paper (notes and tokens) \\
\hline
\end{tabular}

\begin{tabular}{|l|}
\hline \multicolumn{1}{c|}{$\begin{array}{c}\text { FINAL PHASE: } \\
\text { intrinsically valueless of all money (fiat money) }\end{array}$} \\
\hline 7- Gold, silver, non-precious metals, paper \\
\hline 8.- Silver, non-precious metals, paper \\
\hline 9.- Paper and non-precious metals \\
\hline
\end{tabular}

105. The scheme is mine, inspired by the examples Sargent and Velde use in their research and their final summary (Sargent, Thomas. J.; Velde, François R. The Big Problem...: 373-374). 


\subsection{Second branch: Identification and systematic cataloguing of the coins}

In its beginnings, numismatics was dedicated exclusively to identifying and cataloguing the coins that had been preserved through time, either to study them historically regarding the characters from the past who appeared on them, or to look into their metrological characteristics and extract useful conclusions related to monetary practices.

In the $20^{\text {th }}$ century, this original branch grew and consolidated itself with the main aim of identifying and cataloguing the known coins, which became historical documents. Cataloguing and arranging is not only a mechanical task, far from historical reflection. Once created, the overview that a numismatic catalogues supply can enable conclusions to be drawn and lead to a new summary or a new paradigm of the discipline. This first branch has continued (with exceptions) to use the name of 'numismatics' to define the material it studies.

Since the start of the $20^{\text {th }}$ century, the authors and institutions from northern Europe, especially from the Anglo-Saxon world, both British (like the British Museum, the Fitzwilliam Museum in Cambridge, the Ashmolean Museum in Oxford) and American (the Dumbarton Oaks Research Library and Collection, the American Numismatic Society, or the American Hispanic Society), have stood out in this branch of numismatics. The specialised journals and systematic numismatic catalogues produced by these institutions, especially those that cover the ancient epoch, are of world renown. ${ }^{106}$ This tendency is still very much alive nowadays, to a great extent protected by the legislation of these states, permissive in questions of historical heritage, but at the same time, protectors of the conservation of the information. ${ }^{107}$

Regarding the medieval epoch, the most representative numismatist is Philip Grierson (Dublin, 1910-Cambridge, 2006). Born in Ireland, but of English origins, Grierson was the leading exponent of $20^{\text {th }}$ century European numismatic research. ${ }^{108}$ He updated the manual by Engel and Serrure, continuing the same scheme of relating

\footnotetext{
106. To name a few examples: the catalogues of Roman imperial coins: Coins of the Roman Empire in the British Museum. London: British Museum, 1923-1975, 6 volumes; The Roman Imperial Coinage, published in 10 volumes and republished and improved successively since 1923 by Spink of London (The Roman Imperial Coinage. London: Spink \& Son Ltd., 1923-1994, 10 volumes); or also provincial coins: The Roman Provincial Coins. London-Paris: British Museum-Bibliothèque nationale de Paris, 1992-2007, 4 volumes; as well as the catalogue of Byzantine coins: Catalogue of Byzantine Coins. Washington: Dumbarton Oaks, 1968-2006, 5 volumes; and the catalogue of Arab coins: Sylloge of Islamic Coins in the Ashmoleam. Oxford: Ashmolean Museum, 1999-2002, 10 volumes; among many others.

107. Especially in Great Britain, where the law has encouraged findings to be notified to the relevant authorities for them to be studied and their historical importance to be decided, respecting private property. The 1996 Treasury Act was especially drafted after the popularisation of metal detectors and it has propitiated the publication, acquisition and exhibition of findings that are exceptional for British heritage. Source: The British Museum. "The Treasure Act". Portable Antiquities Scheme. 12 June 2016 $<$ http://finds.org.uk/treasure>.

108. As well as the book Lucia Travaini has dedicated to him (Philip Grierson, Irish Bulls and Numismatics, ed. Lucia Travaini. Rome: Edizioni Quasar di Severino Tognon, 2011), you can find a biographic report on Grierson in the introduction to Acta Numismàtica 36 by Miquel de Crusafont (Crusafont, Miquel. "Philip Grierson". Acta Numismàtica, 36 (2006): 7-11).
} 
each historical period with a principal monetary denomination, and apparently continuing the generalised idea of relating the evolution of the monetary systems to the evolution of trade and industry. ${ }^{109}$ However, Grierson's work was much more innovative and valuable for his extraordinary knowledge of the written and numismatic sources. ${ }^{110}$ The main starting point for Grierson's work is the use of coins as historical documents. As Lucia Travaini stressed, Grierson was a historian of coins, especially interested in political history and thus, in the iconography, whose first incursion into numismatics was to rectify a poor attribution of a coin. ${ }^{111} \mathrm{He}$ promoted the Fitzwilliam Numismatic Museum at the University of Cambridge and was the promoter of the Medieval European Coinage (MEC) project, which envisages the publication of 14 volumes of cataloguing and study of the issues of European medieval coins. ${ }^{112}$ Grierson was also the author of three of the five volumes of the Catalogue of the Byzantine Coins in the Dumbarton Oaks Collection and in the Whittemore Collection, ${ }^{113}$ the benchmark catalogue for Byzantine coins. Regarding the origin and essence of money, Grierson sides with the chartalists, as do most experts in this second branch. Lucia Travaini makes it clear on discussing the life and work Grierson:

for those who study the history of metal coins and mints — sovereign prerogative par excellence- it seems difficult to believe that some economic theories favour the role of the private sector in creation of coins, in order to make exchanges easier: the cartalist thesis, that instead sees the State's strong role at the origin of the production and use of coins, has been preferred by scholars of different disciplines such as sociologists, anthropologists, and among these Grierson was the one who possibly better than others managed to illustrate his idea, becoming an emblem of this interpretation. ${ }^{114}$

\footnotetext{
109. Grierson, Philip. Coins of Medieval Europe...

110. ${ }^{110}$ Grierson, Philip. The Origins of Money. London: University of London, 1977 (Corrected and reprinted in: Dalton, Georde, ed. Research in economic anthropology. Greenwich: Jai Press, 1978: I, 1-35; and republished in: Arslan, Ermanno A.; Travaini, Lucia, eds. Scritti storici e numismatici. Spoleto: Centro Italiano di Studi sull'Alto Medioevo, 2001: 207-216); Grierson, Philip. Les monnaies. Typologie des sources du moyen âge occidental XXI. Turnhout: Brepols, 1977.
}

111. Philip Grierson, Irish....

112. To date only three volumes have appeared; the one for the Early Middle Ages, by Philip Grierson and Mark Blackburn, in 1986; the volume of Italy, by Philip Grierson and Lucia Travaini, in 1998; and the last one of the Iberian Peninsula, by Philip Grierson, Anna Maria Balaguer, and Miquel de Crusafont, in 2013 (Grierson, Philip; Blackburn, Mark. Medieval European Coinage: Volume 1, The Early Middle Ages (5th-10th Centuries). Cambridge (UK)-New York: Cambridge University Press, 1986; Grierson, Philip; Travaini, Lucia. Medieval European Coinage: Volume 14, South Italy, Sicily, Sardinia: With a Catalogue of the Coins in the Fitzwilliam Museum, Cambridge. Cambridge (UK): Cambridge University Press, 1998; Grierson, Philip; Balaguer, Anna Maria; Crusafont, Miquel de. Medieval European Coinage. Volume 6. The Iberian Peninsula. Cambridge (UK): Cambridge University Press, 2013).

113. Grierson, Philip. Catalogue of the Byzantine Coins in the Dumbarton oaks Collection and in the Whittemore Collection. Washington D.C.: Dumbarton Oaks Research Library and Collection, 1968: II/1,2 ("Phocas to Theodosius III (602-717)"); Grierson, Philip. Catalogue of the Byzantine Coins in the Dumbarton oaks Collection and in the Whittemore Collection. Washington D.C.: Dumbarton Oaks Research Library and Collection, 1973: III/1, 2 ("Leo III to Nicephorus III (717-1081)"); Grierson, Philip. Catalogue of the Byzantine Coins in the Dumbarton oaks Collection and in the Whittemore Collection. Washington: Dumbarton Oaks Research Library and Collection, 1999: V/1, 2 ("Michael VIII to Constantine XI (1258-1453)"). 
In Spain and also, to a lesser extent, in the other countries of Latin Europe, this branch of numismatics has been declining for decades, especially given the difficulties private collecting has had when materialising cooperation with public entities. However, it is true that there have been notable exceptions, which are mentioned below.

The case in France is somewhat more complex: throughout the $20^{\text {th }}$ century, there have been good numismatists backed by the public sector and a good bibliographic production, ${ }^{114}$ but especially focussed on certain historical episodes (the Merovingians, the Carolingians, the strict kingdom of France in the medieval epoch). However, other numismatic series still await carefully cataloguing. Following the same trend mentioned in other Latin states, excellent catalogues of royal coinage from the modern epoch and some regional series from the medieval and modern epochs have recently been published in France, ${ }^{115}$ along with certain monographs from the ancient epoch, all arising from private initiatives.

The quality of these works varies. There are some excellent ones while others, some of which I found it unnecessary even to mention, are at best mediocre and, at their worst, abominable. However, what is sure is that they would all have been better if they had had technical and material support from the institutions that are the exclusive holders of cultural patrimony.

\subsection{Third branch: The working of the monetary systems (what the researching historians need to know)}

Understanding how each monetary system works in a certain area and time is the third target of numismatics that I mentioned at the start of this thesis. It is a subject that has always been of interest, but not in such a similar way. Initially, prior to the $20^{\text {th }}$ century, the mentioned research served to resolve problems posed by the law, given that ancient contracts and scriptures contain obsolete monetary systems or types of money lost in the mists of time, that had to be interpreted and converted into modern legal tender, and also served for learning from the past to improve the future. ${ }^{116}$ Unfortunately, and despite the evident interest, this branch has often been

\footnotetext{
114. As a gratifying example, the manual by Brepols titled Numismatique médiévale (Bompaire, Marc; Dumas, Françoise. Numismatique médiévale...) is an excellent full compendium of everything that one needs to know about the medieval numismatic discipline, logically adapted to the French setting.

115. For example: Yannick, Jézéquel. Les monnaies des comtes et ducs de Bretagne, Xe au XVe siècle. Paris: Maison Florange, 1998; Divo, Jean Paul. Numismatique de Dombes. Corzoneso: Fiorino d'Oro, 2004; Chareyron, Régis. Numismatique féodale drômoise. Saint-German-en-Laye: Éditions Commios, 2006.

116. This is the case of Josep Salat, whose aim was to know about the past to change the future, immersed, as he was, in a monetary context that had varied very little over the last hundred years and that would still have to wait another fifty to see new proposals put into practice. Salat wanted to explain to the rulers of his country all athe monetary errors that had been committed in the historical past and how this legacy could lead to a new, simpler, more practical and competitive monetary system (Salat, Josep. Tratado de las monedas labradas en el Principado de Cataluña, con documentos justificativos. Barcelona: Antoni Brusi, 1818 [2 volumes]; republished by: Salat, Josep. Tratado de las monedas labradas en el Principado de Cataluña, con documentos justificativos. Madrid: Juan R. Cayón, 1982).
} 
sidelined, especially in Spain, in obvious detriment to the credibility of all historical studies, since the lack of numismatic manuals of proven usefulness at the local level prevents research based on monetary data (purchases, sales, prices, loans, etc.) from knowing whether these are correct or not. At the European level, we do find some regions well represented, including Tuscany and the Duchy of Milan, ${ }^{117}$ or royal France. ${ }^{118}$

Carlo Cipolla (Pavia, 1922-2000) was the author of studies that explain the working of the monetary system in a determined territory, specifically in the cases of Florence and Milan. ${ }^{119}$ Thus, he was very interested in currency and the relation of the intrinsic value of the coins with this currency. For example, Cipolla believed it interesting to ascertain and document the equivalent in silver of the unit of account over time. To do so, he proposed following three paths, namely: 1) the analysis of the conserved coins; 2) reading the orders of issue; and 3) researching in the documentation of the mint. Cipolla recognised that if one can reach paths 2 and 3 , it is not necessary to waste time on path $1 .{ }^{120}$ However, despite basing his research exclusively on the written documentation, Cipolla did not hesitate to show his physical knowledge of the coins studied by including images in his works.

Commercial activity is important, but not exclusive, in the lines of Cipolla's studies. In fact, the economic movements he highlights are not necessarily commercial. For instance, Cipolla confirmed the flight of silver coinage from Europe to Egypt and China from the second half of the $14^{\text {th }}$ century because of a certain gold/silver exchange rate in these places and which favoured the phenomenon. ${ }^{121}$ He also even questioned or pointed out some generally accepted mechanisms. Thus, on the belief that related the discovery of mines of precious metals and the making of bigger coins, Cipolla concluded that it was uncertain. For example, in the second half of the $15^{\text {th }}$ century, in southern Germany, specifically in the Tyrol and the area of Saxony and Bohemia, numerous silver deposits were discovered and exploited. Cipolla concludes that the mechanism through which a greater abundance of metal ended up propitiating the minting of heavier coins is not very clear. ${ }^{122}$

In contrast, for this same minting of heavy silver coins, but in the $16^{\text {th }}$ century, Cipolla found a fundamentally commercial (although partly financial) explanation. He argues that the strong expansion in the volume of international financial transactions in the second half of the $16^{\text {th }}$ century must have implied a growing demand for gold pieces. More or less from the 1550s, the increase in demand did not find a proportional rise in the supply. Thus, in one market after another, some

\footnotetext{
117. Cipolla, Carlo M. Il governo della moneta a Firenze e a Milano nei secoli XIV-XVI. Bologna: Il Mulino, 1990 (translated to the spanish and published with the title El gobierno de la moneda: Cipolla, Carlo M. El gobierno de la moneda. Barcelona: Crítica, 1994).

118. Fournial, Etienne. Histoire monetaire de l'Occident Médieval. Paris: Éditions Nathan, 1970; Bompaire, Marc; Dumas, Françoise. Numismatique médiévale....

119. Cipolla, Carlo M. El gobierno de la moneda...

120. Cipolla, Carlo M. El gobierno de la moneda...: 44-45.

121. Cipolla, Carlo M. El gobierno de la moneda...: 160.

122. Cipolla, Carlo M. El gobierno de la moneda...: 16.
} 
payments traditionally made in gold had to be done in silver. In other words, there was an ever more pressing need to mint a heavy silver coin that, in some way, could replace the gold escudo. ${ }^{123}$

Cipolla also highlighted the creation and making of monetary denominations designed initially for fiscal, rather than commercial, purposes. He found that in August 1504, the Florentine mint began to mint another new silver coin. The ordinance that authorised the minting of this coin precisely specified that the reason for it was due to pay the tax for every wine barrel at the gates of the city. ${ }^{124}$ Cipolla was a precursor who indicated various methodological paths to explore.

\subsubsection{Prior considerations about the working of monetary systems}

When studying the working of monetary systems, the prejudices and stereotypes that accompany the numismatic imagery and that can distort any overview should be taken into account.

A first prior consideration is the certainty that money is not a democratic instrument. In fact, few things in the world work democratically. This is a reality that should not surprise us. In contrast, it is not rare for researchers to begin research work conceived, for example, to show such 'surprising' realities as that, in such and such a century, gold coins did not reach the more popular classes but were exchanged among the nobles and the great magnates of the country. And we are tempted to present this fact as a handicap (and thus, also as an injustice). However, it should be the opposite; historical research should be focussed in a direction to enable it to explain complex processes and not secular evidence. As I see it, if we have to talk about gold coinage, it would be worth doing a study to explain the cases contrary to the one mentioned, the moment when the gold coin went beyond its natural area of circulation (the well-off classes) to supply the everyday market (of the popular classes). In these infrequent cases, does the monetary system work better? Is the distribution of wealth fairer in a society that makes gold coins circulate between the rich and the not so rich? These are interesting questions to answer and not at all evident. We find ourselves with the surprise that the response is just the opposite of what, from an initial naive outlook, we had proposed, because the credibility and good working of a monetary system have no relation to popularising the use of gold coinage. ${ }^{125}$ On this question, again, we must note Nicolau Oresme and his followers, and the distortion caused by their widely accepted thinking. If we accept their theory that currency was a public good and that it did not belong to the

123. Cipolla, Carlo M. El gobierno de la moneda...: 29-30.

124. Cipolla, Carlo M. El gobierno de la moneda...: 18.

125. For example, plentiful circulation of gold coins among all sectors of society is documented in Catalonia in the 1620-1626 period. It must be stressed that this was not exactly regarded as a great achievement by the less privileged classes, as getting their hands on overvalued gold coinage, as was the case, was detrimental for the more modest economies. Sanahuja, Xavier. "La moneda de Lleida al segle XVII". Acta Numismàtica, 31 (2001): 116-117. 
king, but to the community, then it would make sense to study a historical period when this was not fulfilled.

A second consideration to bear in mind is that the currency is an instrument that works on the basis of trust. Studies focussed on money, both from the point of view of economic history, history of law or classic numismatics, generally tend to study the (successful or failed) circulation of money mainly from a metalistic point of view. In other words, the relation between the intrinsic value of the metals and the intrinsic value of the currency (medieval or modern) conditions the behaviour and acceptance of the whole monetary system. Obviously, this trait is fundamental but not the only one when it comes to explaining the success or failure of a monetary policy. The human factor, the educated and popular currents of thought, what we could call mentality, also constitutes a very important factor to take into consideration when talking about money. In the West in the period studied, we can distinguish two levels of perception of money and the practices that derive from it. At a high, academic, level we find, for instance, a certain aversion to the Church. ${ }^{126}$ However, this level does not appear to affect the policies applied by the issuing authorities excessively nor the popular behaviour towards money, especially because the reality is obstinate and difficult to hide. At the popular and political level, it is the practical sense and past experience that condition people's response to any monetary action. Thus, the acceptance of the official value of the coins, although obligatory in a coercive way, is only effective when people interpret that their trust will not be misplaced. However, it is not a question of trust in the currency in itself that matters. The real trust, that which lends stability to the currency and so many other aspects of everyday life, is trust in the state, in power, in the issuing authority. It is political trust that generates monetary confidence and tranquillity. So, we can agree that some monetary perceptions need not be altogether real, modified by a superior trust in not being deceived by the issuing authority. For example, in 1626, the mentality of the user accepted that Catalan milled coins could have a slightly lower weight than hammered coins, and less than the weight that would correspond to them by law, in exchange for greater security against counterfeits and fraudulent alterations. We have written evidence of this anomaly, ${ }^{127}$ and it certifies that confidence in a safe coinage (those harder to fake or to be altered) prevailed over any other concern about the real precious metal content. ${ }^{128}$

\footnotetext{
126. Again we can mention Oresme and the 'common good' as a justification for the existence of currency and commercial activities. Or one can quote the phrase Nummus non calved nummos ("money doesn't produce money") by Thomas Aquinas, against usury, but that emerged as a reaction to a context, the $13^{\text {th }}$ century, of great changes and commercial and monetary transformations. Spufford, Peter. Money and its use...: 387.

127. Sanahuja, Xavier. "El problema de la llei i talla de la moneda de plata catalana del segle XVII", Acta Numismàtica 37 (2007): 136-137.

128. In fact, in the maintenance of the current monetary system, that is not based on coins with intrinsic value, popular trust (in the issuing authorities and regulators) also pays a very important role, more than other mathematically quantifiable factors.
} 
In other words, the intrinsic metal content should not exclusively condition the degree of acceptance of a coin, neither before not nowadays. ${ }^{129}$ Trust in the issuing authority and the degree of collective conviction that this trust will not be defrauded is often more important. This is even more so when the coin in question is small change or minor currency, and made with a high percentage of priceless metals. We have clear proof of all that nowadays, where everyone accepts the validity of some money and monetary values that are really no more than virtual money.

\section{State of the discipline in Spain and Catalonia. Perspectives}

\subsection{The work of the pioneers}

In the $19^{\text {th }}$ century, Àlvar Campaner was one of the pioneers in considering numismatics an auxiliary discipline of history, and he dedicated a good part of his work to establishing a method to facilitate this task. The title of one of his main works, Indicador manual de la numismática española ("Manual indicator of Spanish Numismatics"), ${ }^{130}$ is clear enough in that sense. In contrast to earlier authors, whose numismatic research was addressed to politicians and rulers with the aim of changing and improving the actual monetary system, Campaner's work was aimed at scholars, historians and coin collectors who, without any public help, were progressing in the subject. Campaner's manual only served as help for classifying unpublished coins and placing them in space and time.

Those scholars did their work well and were able to produce numismatic catalogues sufficiently useful for their epoch. However, with the passing of time, priorities have changed. Since then, the discovery of unpublished coins and their attribution has multiplied. Documents have been exhumed and laws, orders and bans related to money have been interpreted. In short, a monetary history of Catalonia and Spain has been redone with initially satisfactory results, with names like Alö̈ss Heiss, Joaquim Botet, Miquel de Crusafont, Octavio Gil Farrés, Pío Beltrán Vilagrasa or Antonio Roma Valdés standing out in the medieval and modern fields.

\footnotetext{
129. Many studies have been done mainly focussed on the intrinsic content of the coins, some even drafting evolutionary tables. In one of these works, Gaspar Feliu (Feliu, Gaspar. "L'equivalent metàl-lic d'algunes monedes de compte a l'Edat Moderna". Acta Numismàtica, 21-23 (1993): 456) echoes some words by Morineau (Morineau, Michel. Incroyables Gazzetes et fabuleaux métaux. Les retours des trésors américaines d'après les Gazzetes Hollandaises (XVIe-XVIIe siècle). Cambridge (UK)-Paris: Cambridge University Press-Éditions de la Maison Sciences de l'Homme, 1985) in which he states that the intrinsic value of the coin is the final reference. The factor 'trust', rarely considered, can become a very distorting element of tables and statistics and end up having the last say.

130. Campaner, Àlvaro. Indicador manual de la numismática española. Palma of Majorca: M. Murillo, 1891. republished in Madrid: Campaner, Àlvaro. Indicador manual de la numismática española. Madrid: Juan R. Cayón, 1976.
} 


\subsection{Numismatics, university and prejudices}

Despite the individual efforts mentioned, it is true that numismatics has gradually dropped out of the university academic curricula. In the $19^{\text {th }}$ century, and surely before, numismatics, or the study of old coins, achieved a certain generalised prestige in all the historiographic circuits. The reason is that coins were considered a firstorder historical document, essential to enable the enigmas of ancient civilisations to be deciphered. In Spain, the key for this research was the ability to decipher the inscriptions, in the case of coins in Latin and, especially the alphabet, in the case of coins inscribed in Iber or Phoenician characters. This linguistic pre-eminence led to numismatics being considered a natural complement to other auxiliary disciplines of history, such as epigraphy and palaeography. Later, a fourth speciality, sigillography, was added to the list. This combination of disciplines ended up giving extraordinary results, especially in the classification of Iber coins and the definitive deciphering of the Iber alphabet by Manuel Gómez Moreno. However, that was in 1922. And, since then, over ninety years have passed and dozens of new universities have been set up in Spain with a range of qualifications, degrees and curricular itineraries. However, nowadays, as in the $19^{\text {th }}$ century, numismatics still appears as a fossilised complement to palaeography, diplomatics, epigraphy and sigillography, and always in a nominal last place that often means students do not even have an hour of theoretical classes. ${ }^{131}$ It is true that the old numismatics has received differentiated action in some university studies, but always as an inseparable complement to archaeology, ${ }^{132}$ never as an auxiliary discipline of economic history or chronology. The history of money does not exist as a stand-alone subject in either Catalan or Spanish university studies. ${ }^{133}$

However, not being studied in the universities does not mean that it does not interest anyone. In the $19^{\text {th }}$ century, the scholars who studied money were necessarily collectors, as there were no published reference works available and there was a lack of museums and institutions protecting the historical patrimony. The reference works by Josep Salat, Àlvar Campaner, Francesc Carreras Candi and Joaquim Botet were mainly nourished by collecting, as were the museums. It was

\footnotetext{
131. As an example, the university subjects offered nowadays or in the last ten years include: Paleografia, Diplomàtica, Epigrafia $i$ Numismàtica ("Palaeography, Diplomatics, Epigraphy and Numismatics") (Universitat de Lleida); Cátedra de epigrafía y numismática ("Chair of epigraphy and numismatics") (Universidad Complutense de Madrid); Paleografia, diplomática, epigrafía y numismática ("Palaeography, Diplomatics, epigraphy and numismatics") (Universidad Nacional de Educación a Distancia); Paleografia, diplomática, epigrafía, numismática y archivística ("Palaeography, Diplomatics, Epigraphy, Numismatics and Archivistry") (Universidad de Sevilla); etc.

132. The subject Numismàtica antiga ("Ancient Numismatics") has been taught in some Spanish and Catalan universities, such as the University of Barcelona. However, I do not recall that a consolidated subject of medieval or modern numismatics (or history of money), unlinked from epigraphics in any university, has ever been taught.

133. A curious data is that when you ask Google about the words catedràtic de numismàtica ("professor of numismatics") in Spanish, the first results refer to the endearing Pantuflo Zapatilla, father of the twins Zipi and Zape created by the genial artist Josep Escobar, who was also a professor of philately and pigeon breeding.
} 
precisely those scholarly collectors who fought to form the first public numismatic cabinets. Thanks to that, Catalonia has an extensive body of numismatic works, one not found in any other national historiography of the epoch. ${ }^{134}$ With time, the meaning of words changes and collecting has become an activity, if not considered almost criminal, one viewed at least as unhealthy. This is disparagement to the relation between numismatics and collecting. Paradoxically, however, private collecting is still conceived as a means of studying and divulgating objects from the past, while the gradual increase in public collecting has not been large enough to meet the challenge. In this country, still nowadays, coin collecting is the epicentre for the study and divulgation of the history of money, while the contributions to this theme from the universities or the 'museums of money' seem more aimed towards accumulating 'treasures' than to historical research. The merit of private collecting is enormous, bearing in mind that in Spain it is accused of misappropriation of that which 'belongs to everyone', invoking a badly understood historical heritage. ${ }^{135}$ This problem does not exist, for example, in Britain, where the Treasure Act facilitates the exchange of information between the institutions responsible for protecting the heritage and the collectors. ${ }^{136}$ There, the most valued treasure is information, and not the accumulation of objects in the showcases and stores of the museums, while in Spain information is often lost for fear of reprisals. ${ }^{137}$ Despite everything, the selfless collaboration of private collectors has enabled the data, information and images necessary and vital for the study of the coins to be gathered. That is why, even from a corporative outlook in favour of historians, conservators and researchers, it is necessary to protect and promote private collectors, one of the few groups willing

134. Josep Salat gave his collection to the Barcelona Board of Trade in the early $20^{\text {th }}$ century, and from there, it went to the old Provincial Museum of Antiquities in Barcelona. Later, other numismatists managed to have the Numismatic Cabinet of Catalonia created in 1932.

135. The preamble to the 1985 Spanish Law of Historical Heritage, still in force nowadays, ends with the following phrase that, given the absence of nuances, helps the mentioned misinterpretation: Porque en un Estado democrático estos bienes [de interés cultural] deben estar adecuadamente puestos al servicio de la colectividad en el convencimiento de que con su disfrute se facilita el acceso a la cultura y que ésta, en definitiva, es camino seguro hacia la libertad de los pueblos ("Because in a democratic state these assets [of cultural interest] must be adequately placed at the service of the community in the conviction that, with their enjoyment, access to culture is facilitated and that, in short, this is a sure path to the freedom of the peoples". Boletín Oficial del Estado. "Ley 16/1985, de 25 de junio, del Patrimonio Histórico Español. Preámbulo". Agencia Estatal Boletín Oficial del Estado. 12 June 2016 < https://www.boe.es/buscar/doc.php?id=BOE-A-1985-12534>.

136. The 1996 Treasure Act is a law passed by the British Parliament envisaged to control the findings of treasure in England, Wales and Northern Ireland. The law requires those who discover objects (or those considered of possible historical interest, like coins) to show them to the designated local authorities, who then decide if the object is treasure or not. If it is declared to be treasure, the owner has to offer it for sale to a museum for a price set by an independent commission (Treasure Valuation Committee). If the museum shows no interest in the object, or is unable to acquire it, the owner keeps it at the end of the process, which is not particularly long. The guarantee of equanimity impedes objects from being exported illegaly or the owners having to hide them. And what is most important is that, throughout the process, independently of whether the objects are acquired or not, the museums are able to examine, record and study them all.

137. I published some reflections on the historical heritage and its management. Sanahuja, Xavier. “El patrimoni històric equivocat". Acta Numismàtica, 39 (2009): 5-9. 
to spend an evening attending a talk or spend money buying a book or pay to visit an exhibition about the subject they like. In short, numismatic researchers have to support the collectors, because they make up a group that consumes history and thus, in the long term, ensure the continuity of historical research and its economic viability. They also have to facilitate the collaboration necessary between the two groups who can make historical research possible: the amateurs and collectors who are interested in the subject and the professional researchers who study it with public funds in the framework of the universities and academies.

\subsection{The need for systematic cataloguing}

Knowing the real difficulties of numismatics in Catalonia and Spain, it is no surprise that the discipline needs a renewal and an important increase in the level of demand. In 2015, numismatic research in Catalonia and Spain is still done individually. However, the works of special difficulty, as in the case that concerns us here, improve exponentially with the participation of various researchers. Moreover, except for a few exceptions in Catalonia, the catalogues have not been updated, and have not made use of the avalanche of information from the virtual networks. This avalanche of information gives us easy access to public and private collections, or to the stocks of dealers, archives, etc.

In fact, there is very little satisfactory systematic cataloguing of series of coins from before 1700. There are few catalogues published in Spain with public support, and all focus on the ancient world. Notable among these are those by Pere Pau Ripollès and his team in Valencia. ${ }^{138}$ Only very recently, thanks to the fall in publishing costs and the growing ease of sharing information through Internet, some private initiatives worth mentioning have appeared. In Spain, the first serious attempts to systematise Castilian small change have gone ahead thanks to a purely private initiative. This is the cataloguing of the billon coin of Henry IV of Castile (1454-1474) by Antonio Roma and José Luis Braña, and the cataloguing I have published, together with Íñigo Jarabo, about the Castilian billon coinage of the Austrians (1566-1718). In Catalonia, the systematic catalogues by Anna Maria Balaguer about the coinage in the Catalan counties (785-1503), ${ }^{139}$ Miquel de Crusafont on Catalan medieval coinage (785-1516) and the Catalan Revolt (1640-1652) ${ }^{140}$ and Leandre Villaronga on the ancient money in the Iberian Peninsula, have all been produced outside the

\footnotetext{
138. Amandry, Michel; Burnett, Andrew; Ripollès, Pere Pau. The Roman Provincial Coinage. LondonParis: University of Oxford, 1992: I; Ripollès, Pere Pau. La ceca de Arse-Saguntum. Sagunt: Fundació Bancaixa, 2002; Ripollès, Pere Pau. Las monedas provinciales romanas de Hispania. Madrid: Real Academia de la Historia, 2010; Gozalves, Manuel. La ceca de Turiazu: monedas celtíberas en la Hispania republicana. Valencia: Diputació de València, 2009; Llorens, Maria del Mar; Aquilué, Xavier. Ilercavonia-Dertosa $i$ les seves encunyacions monetàries. Barcelona: Societat Catalana d'Estudis Numismàtics, 2001; among others.

139. Balaguer, Anna Maria. Història de la moneda dels comtats....

140. Crusafont, Miquel. Numismàtica de la Corona Catalano-aragonesa medieval (785-1516). Madrid: Vico, 1982 (Catalan edition); Crusafont, Miquel; Comas Ezequiel, Rafael. El florí d'or català: Catalunya, València, Mallorca. Barcelona: Asociación Numismática Española-Societat Catalana d’Estudis Numismàtics,
} 
university, but with the support of the Societat Catalana d'Estudis Numismàtics. In Valencia, a work by Josep Antoni Sendra that will include all the coins from the kingdom since the Christian conquest is in an advanced stage.

I am pleased to note a generalised positive tendency in all countries, which is the gradual appreciation of the small currency, that of small value. Since long ago, small change, in copper or bronze, has been much less studied than gold and silver coinage. There are several reasons for this. These pieces are difficult to read and identify and, until recently, there were not many examples known, unlike nowdays thanks to the popularisation of metal detectors. Nor had collectors paid much attention to them, preferring to concentrate on more attractive coins minted in precious metals. The result is that, despite having appeared with the aim of becoming reference catalogues, some works ignored or undervalued the always difficult small change. ${ }^{141}$

\subsection{A practical manual is required}

The most notable shortcoming of Catalan and Spanish numismatics is, however, not having made the technical information from so much individual research available for researchers who are not specialised in the subject. In other words, there is a lack of a numismatic tool to assist historians to understand the workings of the monetary systems at a specific moment. Many renowned voices have long called for an auxiliary tool of these characteristics. As an example, in 1996, in the prologue of a book by Miquel de Crusafont, the historian Josep Fontana explained that when he began to do research into the modern times, the problems that required better understanding of the monetary questions appeared everywhere, and only the old technical books of coin exchanges, intended for the everyday use of the Catalans of two hundred years ago, helped him, in the end, to resolve the fundamental problems. ${ }^{142}$

If the problem of coins in the late $18^{\text {th }}$ century was quite cumbersome, it must have been more so with less well-documented coins from bygone centuries. It is still troublesome, because no practical consultation tool to answer the monetary problems posed by researchers has been published.

We must correct this serious historiographic shortcoming, which hinders our understanding of many historical processes related to the effective use of coins

1996; Crusafont, Miquel. Catàleg General de la Moneda Catalana. Barcelona: Societat Catalana d'Estudis Numismàtics, 2009.

141. This happened, for example, with the catalogues of Muslim coins in the Bibliothèque nationale de Paris (Lavoix, Henri. Catalogue des monnaies musulmanes de la Bibliothèque Nationale. Paris: Imprimerie Nationale, 1887-1896 [3 volumes]. Reprinted in Bologna: Lavoix, Henri. Catalogue des monnaies musulmanes de la Bibliothèque Nationale. Bologna: Arnaldo Forni, 1977) and the British Museum (Lane-Poole, Stanley. Catalogue of the Oriental Coins in the British Museum. London: Printed by order of the trustees, 1875-1890 [10 volumes]), or recently with those on Visigoth coinage (Pliego Vázquez, Ruth. La moneda visigoda. Seville: Universidad de Sevilla, 2009 [2 volumes]).

142. Crusafont, Miquel. Història de la moneda catalana.... 
(quantities of money, penalties and taxes), with government funding or with the intervention of complex or simple commercial transactions.

A numismatic manual for the use of the historian should at least include the following tools to help research:

1. Identification of the currency systems in use in each of the states in the Iberian Peninsula, from the downfall of the political structures of the Roman Empire to the appearance of the decimal monetary systems $\left(5^{\text {th }}-19^{\text {th }}\right.$ centuries $)$. At this first level, the distinct coins in general circulation must be identified and differentiated indicating their geographic frontiers, their temporal limits as official or officious systems, or the overlap of different systems in the same territory in determined historical moments, however without going into the description and differentiation of the coins (i.e. florins, croats, escudos, etc.).

2. Identification of the successive monetary series produced and/or in circulation in each of these states until they were abandoned, including the documentation these issues and checking the composition of the alloys used in them. This second level should include the physical identification (formal, but also metallic) of the different monetary types that have appeared throughout history, paying special attention to correcting errors of appreciation and indicating the difficulties that have yet to be resolved, which are especially detectable in the early centuries of coin production $\left(8^{\text {th }}\right.$ to $13^{\text {th }}$ centuries). Among the coins, distinctions must be made between the country's own currency, foreign currency, bullion, provisional or obsidional money, tokens or private money, etc.

3. The preparation of verified tables with the names the coins were given (official, nominal, popular, with other less widely used ones like the denominations used abroad or among minority groups) and their exchange values (between each other and with other contemporary currencies), whether established officially, officiously or freely set by everyday customs or use among private individuals. This third point is the most useful tool for the researchers who need to be able to identify, and properly assess, the coins that appear in the commercial, financial or administrative transactions of the documents they use in their research. The chronological succession of these tables has never been prepared for a single publication, and only some of them have been published partially, without combining denominations with exchange values with respect to other coinage or currency used.

4. The verified serialisation of the minting of each given type of money, including information on the start date, end date and place of manufacture, geographical area of circulation, and the dates of the beginning and end of the official or officious circulation in a particular territory. This information is essential to enable a specific coin to be related to the historical environment where it circulated. Beyond the documentary aspect and its didactic or illustrative possibilities, the utility of this information lies in providing other auxiliary sciences of history, such as chronology or archaeology, with valid starting points for building hypotheses based on the scientific method. 
5. The chronological indexing of monetary documents published in each of the states mentioned. This is a task of numbering and ordering all monetary documents known and noting the work from where they have been transcribed, recorded or identified in order to facilitate a quick documentary search for the researcher.

6. The making of a glossary of specialised terms, including words related to the manufacture and circulation of currency, specifying the time and, where applicable, geographic extent of this use. I think it is necessary to specify the language as much as possible, to help to dispel confusion and misunderstandings or important nuances.

All this volume of information has to be compiled with scientific criteria and bearing in mind that, in the $21^{\text {st }}$ century, works of special difficulty cannot be signed by a sole author, although he or she is a renowned expert. And, if there are not enough experts, let us first train more. 